\title{
Idiopathic Hypogonadotropic Hypogonadism- An Update on the Aetiopathogenesis, Management of IHH in Both Males and Females-An Exhaustive Review
}

\author{
Kochar Kaur Kulvinder'1, G. N. Allahbadia ${ }^{2}$, M. Singh ${ }^{3}$ \\ ${ }^{1}$ Dr Kulvinder Kaur Centre for Human Reproduction, Jalandhar, India \\ ${ }^{2}$ Rotunda Centre for Human Reproduction, Mumbai, India \\ ${ }^{3}$ Swami Satyanand Hospital, Jalandhar, India \\ Email: kulvinder.dr@gmail.com,drallah@gmail.com, gundeep26@hotmail.com
}

How to cite this paper: Kulvinder, K.K., Allahbadia, G.N. and Singh, M. (2016) Idiopathic Hypogonadotropic HypogonadismAn Update on the Aetiopathogenesis, Management of IHH in Both Males and FemalesAn Exhaustive Review. Advances in Sexual Medicine, 6, 50-78.

http://dx.doi.org/10.4236/asm.2016.64007

Received: July 13, 2016

Accepted: August 8, 2016

Published: August 11, 2016

Copyright $\odot 2016$ by authors and Scientific Research Publishing Inc. This work is licensed under the Creative Commons Attribution International License (CC BY 4.0).

http://creativecommons.org/licenses/by/4.0/ c. (i) Open Access

\section{Abstract}

Methods: Asystematic literature search was performed using PUBMED for all English articles up to April 2014. Although this review mainly focuses on published human studies, it also draws attention to where future research should be directed based on animal studies. Results: Besides the 9 known mutations widely quoted for KS namely KAL1, Fibroblast growth factor 8 (FGF8), fibroblast growth factor receptor 1 (FGFR1), prokineticin 2 (PROK2), PROK receptor 2 (PROKR2), WDR11, heparin sulfate-6-O-Transferase (HS6T1), chromodomain helicase DNA binding protein 7 (CHD7) and semaphorin 3A (SEMA 3A), additional mutations in "FGF8 synexpression" group e.g., FGF 17, ILRD, DUSP 6, SPRY4 and FLRT3 have been shown to be involved in $\mathrm{CHH}$, mostly KS besides SEMA 7A. Although traditionally division has been based on anosmic/normosnic criteria, further genes found to cause so called nIHH like Gonadotropin releasing hormone receptor (GNRHR). KISS1, TAC3, TACR3 have also been found to be associated with hyposmia on detailed testing on UPSIT and MRI for olfactory structures revealed absent OB. Further detailed examination of transcription factor genes have revealed involvement of HESX1, TSHZ1, AXL, SOX10 with a strong overlap of in transcription factors in development of septooptic dysplasia (SOD), combined pituitary hormone deficiency (CHPD) and KS. Treatment with $\mathrm{rFSH}$-hCG gives almost similar results to pulsatile GnRH therapy and should be based on cost factor, availability and in occasional cases specific treatment like kisspeptin therapy. Conclusions: Contrary to the traditional thinking, one shoud reconsider classifying cases of IHH simply on basis of anosmia/normosmia. Deafness calls for looking for mutations in Sox 10/CHD7/ILRD7 considering 38\% associ- 
ation of former. Therapy should be individualized based on availability of pulsatile $\mathrm{GnRH}$, cost factor and in recalcitrant cases kp therapy may be of use with kp mutations and NKB mutations.

\section{Keywords}

Idiopathic Hypogonadotropic Hypogonadism, Kallmannsyndrome, Anosmia, Hyposmia, Normosmia, Gene Mutations

\section{Introduction}

Idiopathic hypogonadotropic hypogonadism ( $\mathrm{IHH}$ ) is characterized by the absence of spontaneous pubertal development in the face of low sex steroids and gonadotropin levels with otherwise normal pituitary function. When associated with anosmia this $\mathrm{HH}$ is termed Kallmanns Syndrome (KS) whereas isolated HH with a normal sense of smell is termed normosmic IHH (nIHH). The incidence varies from 1:10,000 - 140,000 with male:female ratio 4:1 with males presenting every 1:8000 [1]. In most patients with IHH, physiological GnRH response restores normal levels of pituitary and Gonadal hormones, allowing for testicular growth and spermatogenesis in men and ovulation in women [2].

Studies on critical roles of mutated genes causing human GnRH deficiency in the fate specification, proliferation, developmental migration, secretory function and/or survival of GnRH neurons have formed the bases of much of our current understanding of GnRH biology [3].

Human studies in KS fetuses with olfactory bulb agenesis revealed that premature interruption of the olfactory, vomeronasal ( $\mathrm{VN})$, and terminal nerve fibers in the fronto nasal region disrupts the migration of GnRH-1 cells which normally migrate from the nose to the brain along these nerve fibers [4] [5].

\section{Aetiopathogenesis of Ks}

Developmental abnormalities in this migratory journey like those demonstrated with the deletion of the KAL1 gene results in KS [6] [7]. Besides that the fibro blast growth factor (FGF) signaling pathway genes (FGF8 and FGFR1) [8]-[10], Prokineticin 2 (PROK2) signaling pathway genes [11]-[16] and chromodomain helicase DNA-binding protein7 genes (CHD7) [17]-[19], and WDR11 [20], SEMA3A [21] [22] genetic pathways have been identified to haveidentical neurodevelopmental function and implicated in aetiopathogenesis of KS.

WDR11 is an intracellular protein that interacts with the transcription factor EMX1 and semaphorin $3 \mathrm{~A}$ a secreted protein involved in axonal path finding acting through neuropilin (NRP)1 receptors [21]. Subsequently Cariboni et al. in mice studies suggested SEMA 3A signals reduntantly through both the classical NRP1 and unconventional NRP2 while the usual NRP2 ligand SEMA 3F is dispensable for this process and 
suggesting mice lacking it recapitulate the anatomical features of the single KS case analyzed [23]. Further Kansakoski et al. 2014 have further included SEMA 7A besides SEMA3A while screening 50 Finnish children (34KS, 16nIHH). They found 3 heterozygous gene variants c458A $>\mathrm{G}$ (p.Asn153Ser), c.1253A > G (p.Asn418Ser) and c.1303G > A (p.Val435Ile) in SEMA 3A in $3 \mathrm{KS}$ patients who also had a mutation in FGFR1. Two rare hetrogenous variants c.442 C > T (p.Arg148 Trp) and c.1421G > A (p.Arg474Gln) in SEMA 7A were found in one maleKS patient with a previously identified KISS $1 \mathrm{R}$ nonsense variant and one male patient with previously identified KAL1 mutation respectively. They thus concluded that SEMA 3A/SEMA 7A heterozygous missense variants may modify the phenotype of IHH but most probably are not sufficient to cause the disorder alone [24].

The identification of zinc finger homeodomain factor tea shirt finger family member 1 (TSHZ1), a key regulator of mammalian olfactory bulb (OB) development not only in mice but also in humans as revealed by Ragancokoya et al. has given some answers to a lot of unanswered questions regarding role of PROK2 ligands acting through their Gprotein coupled receptors PROKR2 regarding how their mutations cause both KS and IHH [25]-[28]. They investigated families with congenital aural atresia, heterozygous for loss of function mutations in TSHZ1, and found by microarray analysis, ISH, as well as CHIP that TSHZ1 bound to and regulated the expression of the gene encoding PROKR2, a GPCR essential for OB development and thus giving a clue to the link between PROK2 and KS despite GnRH neurons lacking PROK2 receptors [29]. The OB is one of the few areas in the mammalian brain that produce neurons throughout life. New interneurons originating from progenitors in the subventicularzone (SVZ) are continually added to the OB. While mRNA of both PROKR1/PROKR2 are expressed in the SVZ and OB, only PROK2 mRNA found here, which functions as a chemo attractant for these neuronal progenitors which follow a rostral migratory stream [28].

Some of the Prokineticin receptor 2 mutations are not routed to the cell surface, instead they are trapped in the cell secretory pathway. The cell permeant agonist/antagonists have been used to rescue some membrane receptors that are not targeted onto the cell membrane. Chen et al. chose three disease associated mutations W178S, G34D, P290S, which all resulted in retention of PROKR intracellularly. They showed that a small molecule, PROKR2antagonist A457 dramatically increased cell surface expression and rescued the function of P290S PROKR's but had no effect on W178S and G234DPROKR2, Interestingly one of PROKR2 mutations P290S is identified in more than $5 \%$ of Maghrebian KS patients who show PROKR mutations in $23.3 \%$ of their KS population as opposed to $5 \%$ in KS patients from general populations, which have a monogenicrecessive or digenic/oligogenic transmission [30]. Treatment with "chemical chaperones" like $10 \%$ glycerol significantly increased the cell surface expression and signaling of P290S and W178S PROKR2. They concluded that some KS-associated intracellularly retained mutant PROKR2 receptors can be functionally rescued suggesting a potential treatment strategy for the patients of KS bearing such mutations [31].

Further just like Axl/Tyr 3 null mice have delayed first estrus cycle and abnormal 
cycles due to defect in GnRH neuronal migration and survival Salian-Mehta et al. sequenced coding regions for AXL in 104 unrelated KS and nIHH subjects and found 3 missense AXL mutations (p.L50F, p.S202C and p.Q361P) and one intro variant and 6 bp upstream from start exon 5 in two KS and two nIHH subjects and also tested in mice simultaneously and concluded that functional consequences of AXL sequence variants in patients with IHH support the importance of AXL and the Tyro3 family Axl, Mer (TAM) family in reproductive development [32].

Recently HESX2 homeobox genemutations have been reported in cases of KS and considered that they may cause KS. In a study of 217 cases of IHH/KS along with 192 controls 2 novel heterozygous missense mutations i.e. H424 and p.V75L and a previously identified heterozygous missense mutation p.Q6H were identified in 3 of 217 cases $(1.4 \%)$. All were found in males with KS. This highlights the importance of HESX1 homeobox gene expressen in embryonic stem cells as another important gene in aetiopathogenesis of KS [33] [34]. See Table 1.

\subsection{Validity of Classification of $\mathrm{KS} / \mathrm{Nihh}$ on Basis of Smell/Genetic Testing}

Historically KS and nIHH have been considered distinct clinical entities with KS subjects representing a neurodevelopmental phenotype with a primary defect in $\mathrm{GnRH}$ neuronal migration, whereas nIHH subjects represent a neuroendocrine defect in GnRH secretion Most genes identified in KS subjects have been shown to play a predominant GnRH migratory role (KAL1, NELF1, PROK2/PROKR2/FGF8/FGFR1) [35],

Table 1. KS Genes.

\begin{tabular}{|c|c|c|c|c|c|c|c|}
\hline GENES & KAL1 & FGF8\&FGFR & $\begin{array}{c}\text { PROK2 \& PROK2R } \\
\text { Autosomal } \\
\text { recessive or } \\
\text { oligogenc/digenic }\end{array}$ & WDR11 & HSsST1 & SEMA3A & Chd7 \\
\hline $\begin{array}{c}\text { Modes of } \\
\text { Transmission }\end{array}$ & $\begin{array}{l}\text { Xlinked } \\
\text { recessive }\end{array}$ & $\begin{array}{c}\text { Autosomal } \\
\text { Dominant, } \\
\text { Incomplete } \\
\text { penetrance, or } \\
\text { oligogenic/digenic }\end{array}$ & & $?$ & $\begin{array}{c}\text { Digenic/ } \\
\text { Oligogenic }\end{array}$ & $\begin{array}{c}\text { Digenic } \\
\text { or } \\
\text { oligogenic }\end{array}$ & $?$ \\
\hline $\begin{array}{c}\text { Strategy } \\
\text { for gene } \\
\text { identificaton }\end{array}$ & Cytogenetics & $\begin{array}{c}\text { Cytogenetics and Mouse } \\
\text { Models }\end{array}$ & Mouse Models & Cytogenetics & $\begin{array}{l}\text { C.elegans } \\
\text { MODEL }\end{array}$ & $\begin{array}{l}\text { Mouse } \\
\text { Model }\end{array}$ & $\begin{array}{l}\text { Candidate } \\
\text { genes }\end{array}$ \\
\hline $\begin{array}{c}\text { Prevalence } \\
\text { of mutations in } \\
\text { KS pts }\end{array}$ & $\begin{array}{c}8 \% \text { of } \\
\text { male patients }\end{array}$ & $10 \% \&<1 \%$ & $7 \% \& 3 \%$ & $\leq 1 \%$ & $<1 \%$ & $6 \%$ & $1 \%-6 \%$ \\
\hline
\end{tabular}


whereas genes identified in nIHH subjects have been shown to primarily affect neuroendocrine regulation of GnRH srecretion/action (KISS1R, TAC3, TAC3R, GNRH1, GNRHR) [36]-[42]. The overlap seen in mutations of genes such as FGF8/FGFR1/ PROK2/PROKR1 in both KS and nIHH subjects prompted Lewkowitz Shpuntoff et al. to study the detailed olfactory phenotypic spectrum in a large cohort of patients using MRI to determine olfactory structures and university of Pennsylvania Smell Identification Test (UPSIT), along with genetic testing of IHH $n=286$ (201 male/85 female) with 2183 control (1011 male: 1172 females). They found 31.5\% were anosmic, 33.6\% hyposmic and $34.9 \%$ were normosmic. Most hyposmic (7/11) subjects with MRI data exhibited olfactory structure abnormalities. Of hyposmic subjects $39.5 \%$ harboured mutations in genes involved in neuronal migration (KAL1, PROK2, FGF) which was not unexpected but surprisingly also in genes associated with GnRH secretion like (GNRHR, KISS1, KISS1R and TAC3). The only explanation they could give was that either these patients harbor a oligogenic "second hit" as suggested by Sykiotis et al. that contributes to hyposmia or that there maybe ayet unrecognized neurodevelopmental role in addition to regulating GnRH secretion [43]. Besides that they suggested accurate olfactory phenotyping can inform regarding the pathopysiology and guide genetic testing [44].

Further Valletti et al. studied 36 patients (31 males) of IHHand on basis of smell test classified them to be normosmic $(\mathrm{n}=21.58 .3 \%)$ and anosmic/hyposmic $(\mathrm{n}=15.41 .6 \%)$ and found anosmia/hyposmia is significantly related to anatomical anomalies of the olfactory bulb/tracts, but the prevalence of other developmental anomalies, especially midline defects and neurosensorial hearing loss was high both in HH and KS independent of anosmia/hyposmia. Hence they postulated that from clinical standpoint KS and normosmic $\mathrm{HH}$ should be considered as the same complex, developmental disease. Since there are a lot of lacunae in this study, namely small numbers, not using UPSIT for smell detection and study being partially prospective, partially retrospective it is difficult to draw meaningful conclusions [45].

\subsection{Paradox in ICA (Role of OB in GnRH Development)}

However this has been further complicated by Moya-Plana reporting isolated congenital anosmia (ICA) and olfactory bulb agenesis without gonadotropin deficiency with threePROKR2 mutations previously described for KS along with one new PROK2 mutation, and incomplete penetrance on investigation of families, on screening for KAL1/FGF8/FGFR1/PROK2/PROKR2 mutations in 25 cases of ICA which suggests the considerable complexity of GnRH neuron development in humans [46].

While studying 13 most common IHH/KS genes in 48 patients the overall prevalence of digenic gene mutations was found to be $12.5 \%$ by Qyaynor et al. In addition $30 \%$ of patients without a known mutation had mutation in a single gene. Similarly Sykiotis et al. as well found digenic disease in $11 \%$ of 89 patients who had known mutation in one gene and 10 (2.5\%) of 397 among allpatients which is the largest series published [43]. These findings suggest with current knowledge that most IHH/KS patients have monogenic etiology [47]. 


\section{Role of FGF in GnRH Development}

The discovery of mutations in FGF8-FGFR1 in $\mathrm{CHH}$ has demonstrated a previously unappreciated role of FGF8-FGFR1 signaling in GnRH ontogeny. Subsequently Chung et al. have established FGF8 as critical for both GnRH as well as olfactory system development [48]. Besides that ears, eyes, kidneys and limbs are also influenced by FGF8 [49]-[52], all of which can be affected in $\mathrm{CHH}$ [53]. Among the $>15$ genes implicated in $\mathrm{CHH}$, mutations in FGF8-FGFR1 account for $12 \%$ of cases and importantly KAL1 and HS6ST1 (Heparan sulfate-6-O-sulfotransferase 1) [MIM 604846], two genes known to be mutated in $\mathrm{CHH}$, also encode important components of FGF8-FGFR1 signaling. KAL1 encodes anosmin 1, which enhances FGFR1 signaling by direct physical interactions with the FGFR-FGF-heparansulfate proteoglycan (HSPG) complex on the cell surface. HS6ST1, which encodes a heparansulfotransferase enzyme was found mutated in $\mathrm{CHH}$ and that heparan6-O-sulfation was required for anosmin function in vivo [54]. Based on the fact that multiple genes from FGF family are mutated in $\mathrm{CHH}$, Miraouli et al. studied 386 individuals from CHH group with 155 controls to study role of "FGF8 synexpression group" and found except for FGF18 (MIM 6063726) and SPRY2 (Sprouty homolog2) [MIM602466], all other genes were found to be mutated in $\mathrm{CHH}$ individuals FGF17 $(\mathrm{n}=3)$ individuals, IL17RD (Interleukin 17 receptor D)[MIM6068807] $(\mathrm{n}=8)$, DUSP6 (Dual Specificity phosphatase 6) [MIM602748] $(\mathrm{n}=5)$, SPRY4 (Sprouty homolog 4) (Drosophila) [MIM607984] $(\mathrm{n}=4)$, FLRT3 (Fibronectin leucine rich transmembrane protein 3) [MIM604808] $(\mathrm{n}=3)$ while FLRT3 is an enhancer as compared to others which are inhibitors. They further concluded mutations in IL17RD were found only in KS individuals and were strongly linked to hearing loss individuals (6/8). Further mutations in genes encoding components of FGF pathway are associated with complex modes of $\mathrm{CHH}$ inheritance, and act primarily as contributors to an oligogenic genetic architecture underlying $\mathrm{CHH}$ [55]. Animal models indicate that genes involved in FGF8signaling such as KAL1, FGFR1, FGF8 and CHD7 are crucial for both placodal development and cell specification as well as for NC formation, migration and cell survival [9] [56]-[60]. The identification of the neural crest (NC) origin for the olfactory ensheathing cells (OEC) which indicates that all ensheathing glial cells of the peripheral nervous system of head, cranial ganglia, olfactory and auditory system are of NC origin of the OEC and the identification of pluripotent NC derived progenitors within the placodally derived structures [61] [62], is an important point when considering the evolution of NC and placodal structures and more broadly the cellular and molecular readout of syndromic pathologies such as CHARGE specific clinical cases of KS [9] [63].

Using different knockout in mouse lines and cre-lox mediated line age tracing fgf8 expression and cell survival was analyzed in the developing nose in relation to the expression of Bone morphogenetic protein $4(\mathrm{Bmp} 4)$ and its antagonist Noggin (Nog) by Forni et al. 2013. FGF8 is expressed by cells that acquire an epidermal/respiratory cell fate and not by stem cells that acquire neuronal olfactory/vomeronasal (VN) cell fate. Ectodermal and mesenchymalsources of Bmp4 control the expression of BMP/TGF $\beta$ antagonist Nog whereas mesenchymal sources of Nog defines the neurogenic borders 
of the olfactory pit(OP).fgf8 hypomorph mouse models displayed severe craniofascial defects, together with overlapping defects in the OP, including i) lack of neuronal formation ventrally where GnRH neurons normally form and ii) altered expression of Bmp4 and Nog with Nog ectopically expressed in the nasalmesenchyme and no longer defining the GnRH and VN neurogenic border and concluding i) FGF8 is not sufficient to induce ectodermal progenitors of the $\mathrm{OP}$ to acquire neural fate and ii) altered neurogenesis and lack of GnRH neuron specification after chronically reduced fgf8 expression reflected dysgenesis of the nasal region and loss of a specific neurogenic permissive milieu that was defined by mesenchymal signals [64].

Recently it was demonstrated that CHD7 is essential for the migration of multipotent migratory NC cells, which migrate from the neural tube to many regions in the embryo, where they differentiate into various tissues including craniofacial and heart structures. In view of this Schulz et al. undertook a genome-wide microarray expression analysis on wild type (WT) and CHD7 deficient (Chd $7^{\text {Whi+ }}$ and $\left.\mathrm{Chd}^{\text {Whi/Whi }}\right)$ mouse embryos at day 9.5 atimepoint of NC cell migration. They identified 98 differentially expressed genes between $\mathrm{WT}$ and $\mathrm{Chd} 7^{\text {Whi/Whi }}$ embryos. Interestingly many misregulated genes are involved in NC and axon guidance; such as semaphorins and ephrin receptors. By performing knockout experinments for Chd7 in xaenopus laevis embryos they found abnormalities in the expression patterns of Sema3a,a protein involved in the pathogenesis of KS in vivo. In addition they found nonsynonymous SEMA3A variants in 3out of 45 CHD7 negative CHARGE patients.. Thus concluding that CHD7 regulates genes involved in neural crest cell guidance demonstrating a new aspect in the pathogenesis of CHARGE syndrome. Sema3a, is conserved regulatory mechanism across different species, highlighting its significance during development [65].

\section{Diagnosis and Differential Diagnosis}

Since genetic testing is becoming complex and costly, Costa-Barbosa et al. suggested prioritizing genetic testing in patients with KS using clinical phenotypes. For example certain clinical feautures commonly associated with genetic causes are synkinesia (KAL1), dental agenesis (FGF8/FGFR1), digital bony abnormalities (FGF8/FGFR1) and hearing loss (CHD7) and these can be useful to prioritize genetic screening, although renal agenesis and cleft lip and palate did not emerge as statistically significant predictors [66]. This is in slight contrast with the report of Dode et al. where they report associations of renal agenesis with KAL1 and cleft lip/palate with FGF8/FGFR1 mutations which was not found in this study [8] [67].

However before coming to a diagnosis of $\mathrm{CHH}$ one must rule out the differential diagnosis of pituitary tumours, or pituitary infiltration by neuroimaging studies like MRI [68] [69], juvenile hemochromatosis by serum iron and serum ferritin levels [70], and a systemic disorder that by undermining nutritional status could affect gonadotropin secretion and pubertal development like anorexia nervosa, celiac disease [71]. Anterior pituitary function must be thoroughly evaluated to rule out hyperprolactinemia [69], primary hypothyroidism, GH, ACTH and investigate adrenal axis or somatotrope axis 
specifically when pubertal delay accompanied with statural retardation and rule out multiple hormone deficiencies. Indeed diagnosis of any associated endocrinopathy of this type will reorient the etiologic diagnosis towards a specific lesional orgenetic disorder [72]-[77], which will thus conclude that the HH is isolated. The most likely differential diagnosis before 18-year is constitutional delay of puberty. Since IHH may present as delayed puberty, it becomes essential to know how to distinguish constitutional delay of growth of puberty(CDGP) from isolated $\mathrm{HH}$ with definitive diagnosis of IHH awaiting lack of spontaneous puberty by 18years.Although basal gonadotropins and GnRH Stimulation tests have limited diagnostic specificity, with overlap in gonadotropin levels between adolescents with CDGP and IHH, Stimulation tests using more potent GnRH agonists (especially leuprolide acetate) and/or human chorionic gonadotropin (hCG) may have better discriminatory value, but small study size, lack of replication of diagnostic thresholds, and prolonged protocols limit clinical application. Basal inhibin B may offer a simple discriminatory test, however in a recent metaanalysis Harrington J., 2012 didn't find any reliable diagnostic test and recommended this an important area for future investigation ([78] for review and Figure 1).

In paediatric endocrinology this differential diagnosis is far more difficult as $\mathrm{CHH}$ is rare whereas CDGP is infrequent [79]. Serum inhibin B levels in CHH males correlate with testicular volume and thus with clinical severity of gonadotropin deficiency [80]-[82], and with very broad and overlapping values this single marker is not dependent. In view of all difficulties classical clinical feautures distinguishing $\mathrm{CHH}$ from CDGP are still of practical value, especially observing testicular volume over time, in patients receiving exogenous testosterone. In male patient with pubertal delay and low gonadotropins, presence of micropenis and/or cryptorchidism practically rules it out since they are rarely seen in CDGP and favours CHH [79] [83]. Signs of a particular etiology are also useful like anosmia etc. Figure 2 (see [84] for review).

On studying the Brain changes in 45 male patients with KS in a large imaging study Manara et al. found significant morphological and structural brain changes, likely driven by olfactory bulb hypoplasia selectively involving the basal forebrain cortex (which include coirpus callosum changes, multiple sclerosis like white matter abnormalities, acoustic schwanoma in 1 patient). By specific analysis KS patients presentation with symmetric clusters of grey matter volume increase and decrease and white matter volume decrease close to the olfactory sulci, reduced sulcal depth of the olfactory sulci and deeper medial orbital-frontal sulci, lesser curvature of the olfactory sulcus and sharper curvature close to the medial-orbital-frontal sulci and increased cortical thickness within the olfactory sulcus [85].

KS, combined pituitary hormone deficiency (CPHD), and septo-optic dysplasia (SOD) all result from developmental defects of the anterior midline in the human forebrain. It has been recently shown that deficient migration of GnRH neurons is also a feature in forebrain formation defects [5]. Hence Raivio et al. studied 103 patients with either CPHD ( $\mathrm{n}=35)$, or SOD $(\mathrm{n}=68)$ and investigated them for mutations in genes implicated in the etiology of KS (FGFR1, FGF8, PROKR2, PROK2 and KAL1). Muta- 


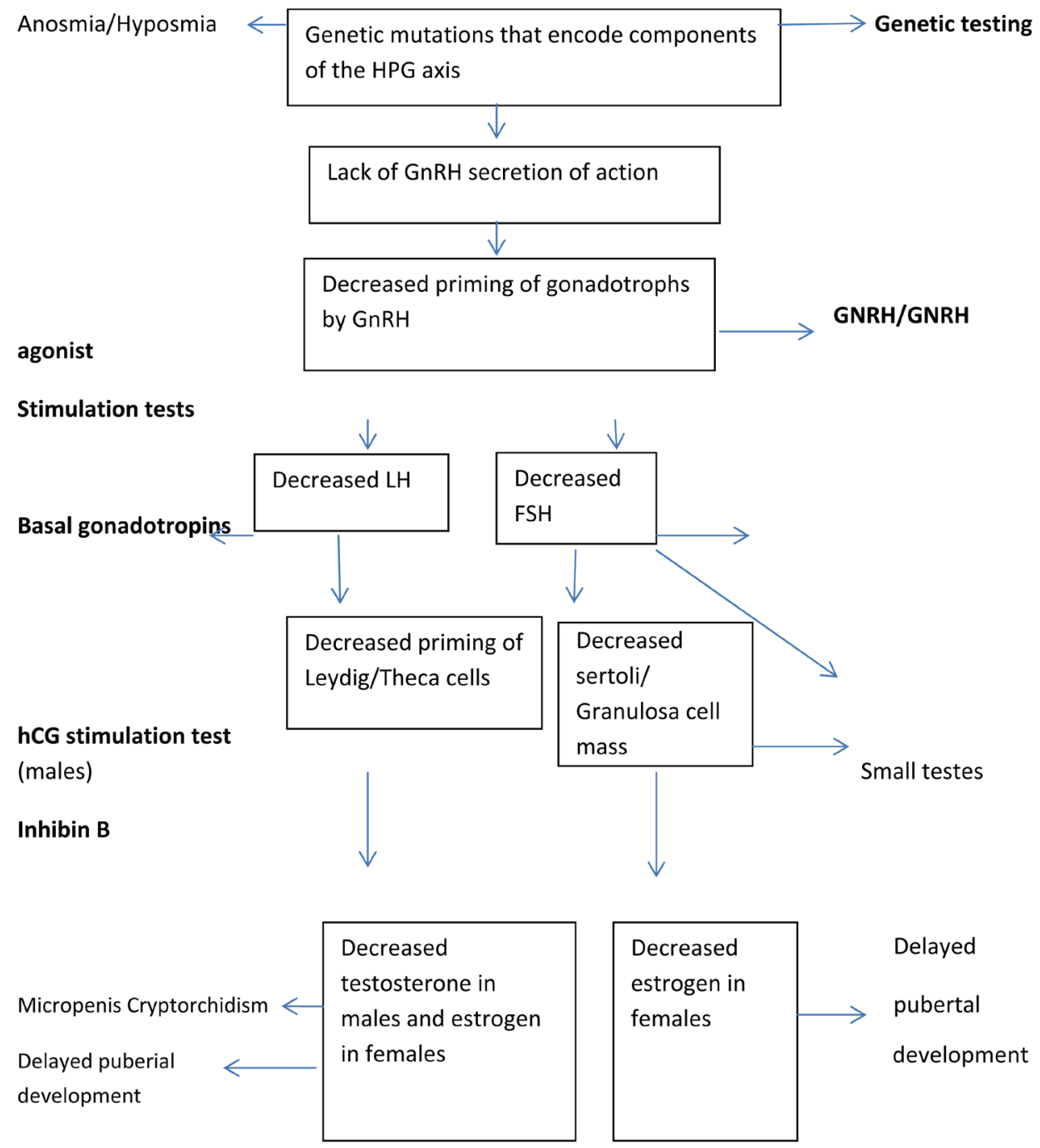

Figure 1. Courtesy ref [78] - In a subset of adolescents with IHH (and Kallmanns syndrome), mutations in genes that encode critical components of the HPG axis lead to either a lack of GnRH secretion, or action. The etiologies in the remaining cases are undetermined. The lack of $\mathrm{GnRH}$ action leads to a deficiency of both priming and hormonal secretion of the gonadotropins in the pituitary and of the leydig/theca cells of the gonads. These characteristics of the H-P-G axis form the physiological basis for the diagnostic tests (indicated in bold face) and typical characteristics (indicated in italic anosmia/hyposmia, small testes, micropenis, cryptorchidism) used to identify patients with a higher likelihood of IHH than CDGP.

tions in FGFR1/FGF8/PROKR2 contributed to $7.8 \%$ of their patients with CPHD/SOD which suggests a significant genetic overlap between conditions affecting the development of anterior midline in the human forebrain. Of the SOD 3 patients had heterozygous mutations in FGFR1,with these either shown to alter receptor signaling (p.S450F, p.P483S) or predicted to affect splicing (c.336C > T, p.T112T). One patient was found to have synonymous mutations in FGF8 (c.216G > A, p.T72T), that was shown to affect splicing and ligand signaling activity. Four patients with CPHD/SOD were found to harbor heterozygous rare loss of function variants in PROKR2 (p.R85G, 


\section{Congenital hypogonadotropichypogonadism}

$(\mathrm{CHH})$

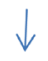

Sense of smell in propositus and relatives

Interview to detect anosmia or deep hyposmia

If apparently normal olfactometry and/or olfactory bulb MRI(1)

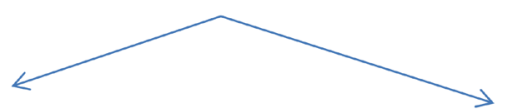

NORMAL

anosmia or

(and without others signs suggesting Kallmann syndrome(2)hyposmia

Or a syndromic cause in the propositus and/or relatives)
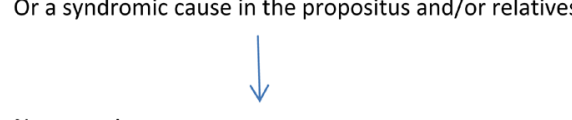

Normosmic

Kallmann (3)

Non syndromic $\mathrm{CHH}$
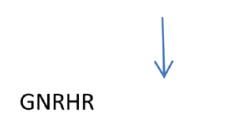

KISS1R

FGFR1 (5)

TAC3 and TACR3

GnRH1

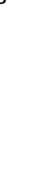

No mutation

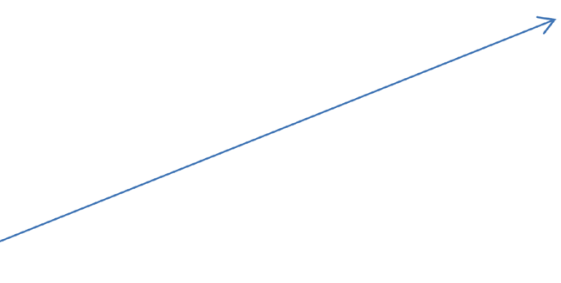

(ormonoallelic mutation)

PROK2/PROKR2 (6)

FGF8

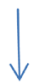

no mutation

$\downarrow$

CHD7. WDR11. NELF (7)

Figure 2. With permission from Dr Young courtesy ref [84]-Molecular studies performed in male patients of $\mathrm{CHH}$ categorized on the basis of smell 1) MRI, 2) Bimanual synkinesis, tooth agenesis, hearing impairment, renal agenesis, cleft lip/palate, high arched palate, pes cavus, ptosis, absent nasal cartilage, hand/foot skeletal abnormalities and iris coloboma 3) Step by step strategy based on familial history and putative mode of disease inheritance (pedigree), and the presence of additional clinical anomalies as mentioned above that may direct the geneticist towards a particular Kallmann gene 4 and 5) For instance 4) KAL 1 is analyzed especially in Kallmann men with mirror movements (bimanual synkinesis) and/or for kidney agenesis and/or when the pedigree suggests an X linked mode of inheritance, whereas 5) in subjects displaying cleft lip/palate FGFR1 mutations are searched in firstline whatever the apparent mode of inheritance 6) in subjects with monoallelic, PROK2 or PROKR2 mutations, search for mutations in other $\mathrm{CHH}$ genes to demonstrate a digenic or oligogenic mode of inheritance 7) Analysis of other large genes mentioned below performed in second line, given their lower or unknown prevalence among normosmic $\mathrm{CHH}$ and Kallmann men.Sizes of the genes currently sequenced in $\mathrm{CHH}$ patients: GNRH1; three exons, GNRHR; three exons,KISS1R;five exons, TAC3; six exons;TACR3;five exons; KAL1; fourteen exons, FGF8, six exons; FGFR1, 18exons; PROKR2, two exons; PROK2, four exons; CHD7; 38exons; WDR11; 29 exons; NSMF (NMDA receptor synaptonuclear signaling and neuronal migration factor-formerly known as NELF); 16 exons. 
p.R85H, p.R268C) [87]. To further study the role of PROKR2/PROK2, McCabe et al. further studied 422 patients of congenital hypopituitarism $(\mathrm{CH})$ and detected that variations in PROKR2 but not PROK2 are associated with $\mathrm{CH}$ and SOD. They detected 5PROKR2 variants in 11 patients with SOD/CH: novel p.G371R and previously reported p.A51T, p.R85L, p.L173R and p.R268C-the latter three being known as functionally deleterious variants [88]. Midline defects are encountered in all three KS [MIM; 147950], SOD [MIM; 182230] and holoprosencephaly [HPE; MIM 236100], a complex brain malformation that affects both the forebrain and face. In view ofmutations identified in number of transcription factor genes in SOD cases such as SOX2, HESX1, SOX3, and OTX2, which are essential for normal forebrain development [89], and similarly in HPE mutations found in genes like SHH, SIX3, TGIF1, TDGF1, FOXH1, and GLI2 [90] [91], Vaaralahti et al. 2012 studied 19 subjects (18 males) with KS without known KS genes and screened them for mutations in SOX2, SHH, SIX3, TGIF1, TDGF1, FOXH1, GLI2 and GLI3. One male carried 2heterozygous missense changes, one in SIX3 (c.428G > A, p.G143D) and the other in GLI2 (c.2509G > A, p.E837 K). Both of these genes have been implicated in etiology of HPE and none was present in 200 control subjects. Thus they concluded that KS and HPE may display a genetic overlap and in view of this the involvement of genes implicated in the etiology of midline defects in patients with KS warrants further studies [92].

Recently a novel syndrome has been defined known as TUBB3E410 K Syndrome where one of the eight missense mutations in TUBB3 gene, that encodes the neuronal specific protein $\beta$ tubulin isotype 3 , have congenital fibrosis of the extraocular muscles, facial weakness developmental delay, and possible peripheral neuropathy. This occurs due to $\mathrm{c} .1228 \mathrm{G}>\mathrm{A}$ resulting in a TUBB3E410K amino acid substitution which directly alters a kinesin moto4r protein binding site. In detailed phenotype of eight unrelated individuals Chew et al. confirmed electrophysiology that a progressive sensorimotor polyneuropathy does indeed segregate with the mutation and expand the TUBB3E410K phenotype to include KS, stereotyped midface hypoplasia, intellectual disabilities and in some cases vocal cord paralysis, tracheomalacia and cyclic vomiting. Neuroimaging reveals a thin corpus callosum, and anterior commisure, hypoplastic to absent olfactory sulci, olfactory bulbs and oculomotor and facial nerves, which support underlying abnormalities in axon guidance and maintenance [86].

\subsection{Management}

Castaneyra-Perdomo et al. 2014 suggested that although normally treatment is started in KS patients just before puberty early treatment isadvisable, as brain sexualmaturation occurs long before puberty normally at perinatal age. As brain cells implicated in the development of the olfactory and reproductive system have a rostraland a caudalorigin, and the rostral origin is affected by aplasia in KS and the caudal origin does not seem to be affected, the aim of early treatment of KS is to attain brain sexualmaturation at the most appropriate age possible, which may prevent the eunuchoidal behavior and appearance observed in KS [93]. 


\subsubsection{Role of Testosterone Therapy}

The initial goal of treatment for adolescents and young men who present with $\mathrm{CHH}$ is to induce physical and behavioral development matching that of normal healthy subjects of same age. This includes development of secondary sex characters like pubic and axillary hair, increase in penis size, voice masculinization and development of muscle mass. Further one aims at correcting the delay in bone maturation and deficient bone mineralization, enhance libido and modify sex behavior. Mostly effective testosterone replacement therapy can lead to a spectacular improvement in quality of life, which demonstrates a causal relationship between testosterone deficiency and these patients symptoms.

Although it is more physiological to achieve such benefits with pulsatile GnRH administration or with combined gonadotropin therapy (human chorionic gonadotropin and FSH) [94] [95], with both therapies effectively inducing testicular growth and secretion of testosterone and estradiol [94]; we have to consider availability of GnRH infusion pumps, cost of treatment, patients requirements specially if patient presents as a partner of an infertile couple with spermatogenesis in view.Since longterm treatment is required even in west mostly testosterone therapy as (injectable esters) is generally preferred for convenience of infrequent injections and cost, DHT is not preferred as it can't be aromatized to estradiol, and hence can't serve the dual purpose of testosterone esters used for decades now as first line treatment. Tn enanthate is one of the cheaper preparations, used at a dose of 200-250 mg once every 2 or 3 weeks. Although these doses depend on age at diagnoses and local practices, Pediatric endocrinologists who see these patients at a younger age, initially prescribe lower doses, gradually increasing for fear of inducing abrupt virilization and bone maturation which could cause behavioral and relational problems. Endocrinologists see adult $\mathrm{CHH}$ patients at a later stage when main signs/symptoms are of severe hypogonadism, and usually require full dose. Although two approaches are not comparable patient should be counseled that he will need longterm androgen therapy. Once full virilization has been induced by exogenous testosterone, males whose testes have significantly increased in size ( $<5 \%$ cases), should be revaluated off androgen replacement therapy to identify those with reversible forms [96] [97] who no longer require treatment.

In a detailed follow up study of 308 patients 44 underwent spontaneous reversal giving a lifetime incidence of $22 \% .15$ patients with reversal (30\%) had KS of which 1 had undetectable OB on brain MRI. Maximum reversal occured in neurokinin B (10\% vs $3 \%$ in nonreversal) although reversaloccurred across broad range of phenotypes and genotypes (including FGFR1, PROKR2, GNRHR). Sidhoum VF et al. 2014 suggested that despite the importance of NKB pathway for normalpubertal timing, its function is dispensable later in life and occurrence of reversal in patient with no $\mathrm{OB}$ demonstrates that this structure is not essential for normal reproductive function. Also patients with IHH require lifelong monitoring for reversal and if reversal occurs for subsequent relapse rates as evidenced in 5 patients who relapsed after reversal [98].

\subsubsection{Role of Gonadotropin Therapy}

Patients who wish to have an increase in testicular volume or fertility in developing 
countries like ours where most centres don't have the facilities of infusion pump the approach of combination therapy with initial $\mathrm{rFSH}$ with the idea of stimulating proliferation of immature sertoli cells which are under control of FSH initial doses of 1.5 $\mathrm{IU} / \mathrm{Kg}(180-450 \mathrm{u} /$ week $) \times 2$ months -2.8 yrs Puberty is then initiated with Hcg $500-$ $4000 \mathrm{IU} /$ week, 1 - 3 times/week sc and after onset of Hcg treatment if patient can't afford can shift to highly purified FSH.Raivio et al. found this induced prepubertal testes growth with increase in serum inhibin B levels,and 6/7 prepubertal boys displayed sperms despite extremely small initial testis primed with rFSH [95] [97] [99]. Similar approach in countries like china followed [100].

\subsubsection{Role of Pulsatile GnRH Therapy}

$\mathrm{GnRH}$ treatment is successful in inducing virilization and spermatogenesis in men with $\mathrm{IHH}$, however a small subset of IHH men, fail to reach a normal testicular volume and produce sperm on this therapy [94]. Pitteloud in studying 76 IHH men undergoing $\mathrm{GnRH}$ therapy for 12 - 24 months to define predictors of outcome of longterm $\mathrm{GnRH}$ therapy concluded anosmia was not an independent predictor, however favourable predictors of achieving an adult testicular size and consequently optimizing spermatogenesis are prior history of sexual maturation, with a baseline inhibin (IB) $>60 \mathrm{pg} / \mathrm{ml}$ along with absence of cryptorchidism [101].

Further extending Sykiotis et al. studied 90 patients and classified patients into four groups according to the response obtained to longterm physiological pulsatile $\mathrm{GnRH}$ release. 67/90 subjects displayed normal expected response, with normal serum T (270 $1100 \mathrm{ng} / \mathrm{dl}), \mathrm{LH}(4.2-17 \mathrm{IU} / \mathrm{L})$ and FSH (1.8 - $14 \mathrm{IU} / \mathrm{L})$ and had sperm in their ejaculate and were labeled as typical responders. In rest 23 patients $(26 \%)$ three distinct patterns were seen 1) 10 men remained hypogonadotropic and hypogonadal with low normal LH/FSH, serum $\mathrm{T}<200 \mathrm{ng} / \mathrm{dl}$ and no sperm despite $\mathrm{GnRH}$ doses upto 800 ng/Kg-and thus labeled Group1 with triple defect with GnRH deficiency, pituitary resistance and testicular failure. 2) 8 men achieved normal serum $\mathrm{T}$ and produced sperms but did so with high LH ( $>17$ IU/L andFSH $>14$ IU/L and thus labeled Group 2 with dual defect, GnRH deficiency and testicular resistance. 3) 5 men remained azoospermic after atleast 21 months despite achieving normal serum T, LH and FSH and thus labeled Group 3 with GnRH deficiency with azoospermia. Although typical responders showed mutations in all the IHH genes tested, atypical responders displayed mutations exclusively in KAL1 Gene [102]. Although Sinisi et al. reported a case with homozygous mutation in PROKR2 gene Val274 Asp which presented as reversible KS along with persistent oligozoospermia [103].

\subsubsection{Role of rFSH Priming Followed by GnRH Therapy}

Dwyer et al. 2013 conducted a randomized open label prospective trial to see if there is any benefit of giving recombinant $\mathrm{FSH}(\mathrm{rFSH})$ pretreatment for 4 months followed by pulsatile GnRH therapy vs GnRH therapy alone in a group of $\mathrm{CHH}$ patients with prepubertal testis $(<4 \mathrm{ml})$, no cryptorchidsm, and no prior gonadotropin therapy and found $\mathrm{rFSH}$ increased inhibin $\mathrm{B}$ levels into normal range and doubled testicular vo- 
lume. Histological analysis showed proliferation of sertoli cells (SC) and spermatogonia, a decreased SC to germ cell ratio from 0.74 to 0.35 and SC cytoskeletal rearrangements. Although with pulsatile $\mathrm{GnRH}$ similar hormones and significant testicular growth was exhibited, all men receiving $\mathrm{rFSH}$ developed sperm in their ejaculate (7/7 vs 4/6 in GnRH only group) and showed trends towards higher maximal sperm counts and hence concluded that $\mathrm{rFSH}$ not only appears to maximize the SC population, but also induces morphologic changes, suggesting broader developmental roles [104]. This maybe in accordance with the study of Pitteloud et al. who found after studying 25 patients of IHH that. GnRH deficient men undergoing GnRH induced sexual maturation displayed an inverse responsiveness to $\mathrm{GnRH}$ and baseline testicular size and I(B) levels. This observation implied that increasing seminiferous tubule maturity represents the major constraint on FSH responsiveness to GnRH in early puberty. In contrast LH responsiveness to $\mathrm{GnRH}$ corelated directly with duration of $\mathrm{GnRH}$ exposure [105]. However in view of small numbers Dwyer et al. proposed that although data appears promising a multicenter trial is recommended to optimize the optimal strategy for treating the very severe $\mathrm{CHH}$ cases.

\subsubsection{Insulin like Peptide 3 (INSL3)}

A testicular hormone secreted during fetal life, neonatal period and after puberty was studied in 281 patients of $\mathrm{CHH} / \mathrm{KS}$ for its diagnostic and investigative regulation. It was found that INSL3 is as sensitive a marker as $\mathrm{T}$ for the evaluation of altered leydig cell function in $\mathrm{CHH} / \mathrm{KS}$ patients. INSL3 levels correlate with $\mathrm{LH}$ levels in CHH/KS men showing together with their rise in INSL3 levels during Hcg therapy and not treatment alone with T that INSL3 secretion seems not constitutively secreted during adulthood but is dependent on pituitary LH [106].

Many studies indicate that the profound FSH/LH deficit is already present during fetal life which explains the micropenis, cryptorchidism and marked testicular hypotrophy already present at birth. Besides that neonatal activation of gonadotropin secretion is compromised in severe $\mathrm{CHH} / \mathrm{KS}$, preventing the first phase of postnatal testicular activation. Finally $\mathrm{CHH}$ is characterized by the persistence of $\mathrm{Gn}$ deficiency in a vast majority of cases at the time of puberty and during adulthood. This prevents the normal pubertal testicular reactivation required for physiological sex steroid and testicular peptide production and for spermatogenesis. Trabados et al. thus proposed further that $\mathrm{CHH} / \mathrm{KS}$ represents a pathological paradox that can help to unravel in vivo, the role of each $\mathrm{Gn}$ in human testicular exocrine and endocrine functions at different stages of development. Recombinant pure Gn's or pure FSH or LH activity have been used to stimulate leydig cells and sertoli cells respectively and thereby to clarify their paracrine interactions in vivo. The effects of these pharmacological probes can be assessed by measuring the changes they provoke in circulating testicular hormone coincentrations. Thus Trabados et al. reviewed the impact of CG deficiency in endocrine function of interstitial compartment which contains T, E2, INSL3, secreting leydig cells, regulation of inhibin B and AMH secreted by seminiferous tubules. Further insights are provided by studies of human testicular stimulation with recombinant stimulation with recombi- 
nant gonadotropins used individually or in combination [107].

\subsection{IHH in Women}

Shaw et al. retrospectively studied 248 female patients of IHH from 1980 to 2010 seen in Massachussets general hospital. The clinical presentation varied from primary amenorrhea and absence of any sexual characteristics to spontaneous breast development and occasional menses. In this cohort rare sequence variants were present in all known genes associated with GnRH deficiency, including novel identification of GnRH deficient women with KAL 1 variants. They concluded that the pathogenic mechanism through which KAL 1 variant disrupts female reproductive development requires further investigation [108].

IHH in women (as in men) is treated with sex hormones. Initially low dose estradiol $(1 \mathrm{mg}$ ) is begun in order to develop sexual characteristics and then it is gradually increased in doses [109]-[112]. From the second year of treatment estrogen supplementation with chlormadinone acetate is done [110]-[112]. Desire for pregnancy warrants pulsatile GnRH therapy to stimulate production of serum FSH and LH [2] [113]. Further the importance of $\mathrm{GnRH}$ administration should be intermittent and pulsatile to be able to restore activity of the reproductive axis in patients with HA and other disorders of GnRH deficiency was emphasized by Knobil et al. [114]. Tonic exposure of GnRH inhibited pituitary gonadotropin scecretion paradoxically [115]. Although chances of success is good, where GnRH is not available, LH or FSH can be administered alternatively [116].

Just like in male subjects Abel et al. repeated the study in $37 \mathrm{IHH}$ women treated with i/v pulsatile GnRH therapy (75 ng/kg/bolus) (retrospective study (1980-2012), all patients over 16yrs with $46 \%$ anosmic and tested for all 14 genes and found that during first cycle $60 \%(22 / 37)$ recreated normal cycles, 30\% (12/37) demonstrated altered gonadotropin response indicating pituitary resistance and 10\% (3/37) an exaggerated FSH response consistent with ovarian resistance. Mutations in CHD7, FGFR1, KAl1, TAC3, TACR3 were documented in IHH women with normal cycles, whereas mutations were identified in GNRHR, PROKR2 and FGFR1 in those with pituitary resistance. Women with ovarian resistance were mutation negative. Thus they concluded that although physiological replacement with GnRH recreates normal menstrual dynamics in most IHH ladies [117], Hypogonadotropic responses in first week of treatment identify a subset of women with pituitary dysfunction, only some of whom have GNRHR mutations.IHH women with hypergonadotropic responses to $\mathrm{GnRH}$ replacement, consistent with an additional ovarian defect did not have mutations in genes known to cause IHH similar to their findings in men with evidence of an additional testicular defect. Hence they hypothesized that identification of women with abnormal responses to physiological GnRH replacement would give greater insight into the pathogenesis of $\mathrm{HH}$. Hyper/hypogonadotropic responses would implicate an ovarian/pituitary defect, respectively. Such findings would suggest that genes involved in gonadotropin or ovarian development and function that are also expressed in the hypothalamus should be given greater consideration in the search for new IHH genes. 
Still controversy exists on the sexuality and intimate relations of men with severe $\mathrm{CHH}$ accompanied by cryptorchidism and micropenis [118]. Since there is a negative prognostic value of cryptorchidism and low testicular volume for the future fertility of patients with severe $\mathrm{CHH}$, a trial of earlier gonadotropin therapy during the neonatal or normal pubertal period is warranted and just may prove beneficial, both in terms of testicular hypertrophy and in terms of future fertility [119]-[121].

\section{Role of Estradiol (in Male $\mathrm{CHH}$ )}

Trabados et al. studying 91 men of $\mathrm{IHH}$, syndrome found male hypogonadism in $\mathrm{CHH}$ is associated with profound E2 insufficiency which can be overcome by aromatizable androgen (Tenanthate) or combined gonadotropin (FSH-HCG) therapy, but not dihydrotestosterone (DHT) contrary to Klinefelters syndrome [122]. This E2 deficiency is also associated with abnormal bone development, noteenage growth spurt and osteopenia or osteoporosis [123]-[125], reviewed in [126]. Further Rochira et al. reported 4 cases of tall stature without Growth hormone deficiency who had a impaired response of GH to GHRH-ARG as compared to normal subjects and who had significantly lower IGF1 levels as compared to normal subjects and both IGF1 peak and concentrations were not modified by estrogen therapy in men with aromatase deficiency and concluded insulin as the cause of tall stature rather than GH for the marked increase in height due to nonclosure of epiphyses [127]. Besides that for normal physiology, Pitteloud et al. 2008 showed that for Inhibition of LH secretion by T in men aromatization is required for its pituitary effect but not its hypothalamic effect [128].

Further since $\mathrm{Kp} 10$ is a potent stimulator of $\mathrm{LH}$ and increases pulse frequency in men and thereby LH and testosterone levels in normal men there may be a potential role of Kp agonists in HH due to KISS 1/KISS1R mutations ([129], reviewed in [130]). Although TAC3/TAC3R mutations also are associated with $\mathrm{IHH}$, administration of $\mathrm{NKB}$ was not accompanied by increase in serum LH and testosterone levels, hence role of NKB doesn't appear to be useful in treating these patients presenting with TAC3/ TACR3 mutations [131] however since KISS1 appears to be downstream of NKB signaling, pulsatile gonadotropin secretion is restored by kisspeptin administration to patients with $\mathrm{HH}$ secondary to NKB and or its receptor [132] [133].

\section{Conclusions}

The very concept of classifying IHH into anosmic/hyposmic KS and normosmic IHH gets challenged by the study of Lewkowitz Shpunoff although till now we have been tuned to working on the basis of KS/nIHH. This was further substantiated by the study by Valetti et al. where olfactory bulb was absent in patients with anosmic/hyposmic $\mathrm{IHH}$, and otherwise there was no difference in the developmental anomalies in the 2 groups. Although this study was a not well conducted in terms of numbers, smell test and neither fully prospective but it does add to the results of Lewkowitch et al. in that there is no point in classifying as two separate disorders but both are part of same spectrum. Despite identification of so many genes like 9 of those which were earlier consi- 
dered as for the KS group as they affect the migration or GnRH development eg KAL1, FGF8. FGFR1, HS-6TS1, CHD7, WDR11, PROK2/PROKR2/SEMA3A these account for not more than $30 \%-32 \%$ cases of KS. Addition of "FGF Synexpression group" adds to the list besides the genes considered so far associated with GnRH function/secretion. Still a lot of controversial issues remain regarding role of PROK signaling as highlighted in ref. [27] regarding absence of PROK receptors on GnRH neurons, mode of inheritance-digenic/oligogenic [43] with presence of PROK2 mutations even in normosmic $\mathrm{HH}$ and thus extending the role beyond olfactory bulb development and GnRH neuronal migratrion and absence of any defect in homozygous mutations while most of human presentations being in heterozygous mutations. Although some answers are provided by the link between TSHZ1, which bound to and regulated the expression of gene encoding PROKR2, a GPCR essential for OB development. Further recently that there maybe an ethnic role is highlighted by greater presence of PROKR2 mutations in KS patients from Maghreb as compared to European origin patients (23.3\% vs $5.1 \%$ ) [30]. Further more work needs to be done on other transcription factors as has been shown for SOX10 i.e., loss of function mutations in SOX 10 is associated with KS along with deafnessal though not in KS without deafness and highlighting importance of neural crest as well as part origin for GnRH neurons [134]. Similar work needs to be done for other transcription factors in view of genetic overlap of other midline forebrain disorders like SOD and HPE with KS. Further genes involved in development of hypothalamus, pituitary and gonads in both males as well as females who fail to respond to pulsatile GnRH therapy should be targeted for understanding reason for 4 - 5 times greater preponderance in males-whether it is explained just by $\mathrm{X}$ linked transmission or we are missing some female cases due to underreporting in mild hypogonadism or primary amenorrhea not brought forward [135]. The role of SDF-GABA signaling in promoting linear axophilic migration of $\mathrm{GnRH}$ neurons through interaction of its receptors, chemokinereceptor 4 and 7 (CXCR4/CXCR7), needs further investigation like other molecules, hepatocyte growth factor (HGF), deleted in colorectal cancer (DCC), Slit2 and Robo3 as suggested by Wray et al. and Cariboni respectively in animal models [136]-[139].

\section{References}

[1] Seminara, S.B., Hayes, F.J. and Crowley Jr., W.F. (1998) Gonadotropin-Releasing Hormone Deficienciesin the Human (Idiopathic Hypogonadotropin Hypogonadism and Kallman's Syndrome) Pathophysiological and Genetic Considerations. Endocrine Reviews, 19, 521539.

[2] Martin, K., Santoro, N., Hall, J., Filicori, M., Weirman, M. and Crowley Jr., W.F. (1990) Clinical Review 15: Management of Ovulatory Disorders with Pulsatile Gonadotropin Releasing Hormone. Journal of Clinical Endocrinology \& Metabolism, 71, 1081A-1081G. http://dx.doi.org/10.1210/jcem-71-5-1081

[3] Bianco, S.D. and Kaiser, U.B. (2009) The Genetic and Molecular Basis of Idiopathic Hypogonadotropic Hypogonadism. Nature Reviews Endocrinology, 5, 569-576. http://dx.doi.org/10.1038/nrendo.2009.177

[4] Schwanzel-Fukuda, M. and Pfaff, D.W. (1989) Origin of Luteinizing Hormone Releasing 
Hormone Neurons. Nature, 338, 161-164. http://dx.doi.org/10.1038/338161a0

[5] Texeira, L., Guimior, F., Dode, C., Fallet-Bianco, C., Millar, R.P., Delezoide, A.L. and Hardelin, J.P. (2010) Defective Migration of Neuroendocrine GnRH Cells in Human Arrhinencephalic Conditions. Journal of Clinical Investigation, 120, 3668-3672.

http://dx.doi.org/10.1172/JCI43699

[6] Franco, B., Guioli, S., Pragliola, A., Incern, B., Bardoni, B., Tonlorenzi, R., Carrozo, R., Mastrini, F., Pieretti, F., Taillon-Miller, P., Brown, C.J., Willard, H.F., Lawrence, C., Persico, M.G., Camerino, G. and Ballabio, A.A. (1991) Gene Deleted in Kallmann's Syndrome Shares Homology with Neural Cell Adhesion and Axonal Path-Finding molecules. Nature, 353, 529-536. http://dx.doi.org/10.1038/353529a0

[7] Legouis, R., Hardelin, J.P., Levilliers, J., Claverie, J.M., Compain, S., Wunderle, V., Millaseau, P., LePaslier, D., Cohen, D., Caterina, D., Bougeleret, L., Delemarre-Van deWaal, H., Lutfalla, G., Weissenbach, J. and Petit, C. (1991) The Candidate Gene for the X Linked Kallmann Syndrome Encodes a Protein Related to Adhesion Molecules. Cell, 67, 423-435. http://dx.doi.org/10.1016/0092-8674(91)90193-3

[8] Dode, C., Levilliers, J., Dupont, J.M., De Paepe, A., Le Du, N., Soussi-Yanicostas, N., Coimbra, R.S., Delmaghani, S., Compain-Nouaille, S., Baverel, F., Pecheux, C., Le Tessier, D., Cruand, C., Delpech, M., Speleman, F., Vermuelen, S., Amalfitano, A., Bachelot, Y., Bouchard, P., Cabrol, S., Carel, J.C., Delemarre-vande Waal, H., Goulet-Salmon, B., Kottler, M.L., Richard, O., Sanchez-Franco, F., Saura, R., Young, J., Petit, C. and Hardelin, J.P. (2003) Loss of Function Mutations in FGFR1 Cause Autosomal Dominant Kallmanns Syndrome. Nature Genetics, 33, 463-465. http://dx.doi.org/10.1038/ng1122

[9] Falardeau, J., Chung, W.C., Beenken, A., Raivio, T., Plummer, E.F., Eliseenkova, A.V., Ma, J., Dwyer, A., Quinton, R., Na, S., Hall, J.E., Huot, C., Alois, N., Pearce, S.H., Cole, L.W., Hughes, V., Mohammadi, M., Tsai, P. and Pittelous, N. (2008) Dexreased FGF8 Signaling Causes Deficiency of Gonadotropin Releasing Hormone in Humans and Mice. Journal of Clinical Endocrinology \& Metabolism, 118, 2822-2831.

[10] Pitteloud, N., Acierno Jr, J.S., Meysing, A, Eliseenkova, A.V, Ma, J., Ibrahim, O.A., Metzger, D.L., Hayes, F.J., Dwyer, A.A., Hughes, V.A., Yialamas, M., Hall, J.E., Grant, E., Mohammadi, M. and Crowley Jr., W.F. (2006) Mutations in Fibroblast Growth Factor Receptor 1 Causes Both Kallmann Syndrome and Normosmic Idiopathic Hypogonadotropic Hypogonadism. Proceedings of the National Academy of Sciences of the United States of America, 103, 6281-6286.http://dx.doi.org/10.1073/pnas.0600962103

[11] Dode, C., Teixeira, L., Levvilliers, J., Fouveaut, C., Bouchard, P., Kottler, M.L., Lespinasse, J., Lienhart-Roussie, A., Mathew, M., Mierman, A., et al. (2006) Kalmann Syndrome: Mutations in the Genes Encoding Prokineticin 2 and Prokineticin Receptor 2. PLoS Gene, 2, e175. http://dx.doi.org/10.1371/journal.pgen.0020175

[12] Pitteloud, N., Zhang, C., Pognatelli, D., Li, J.D., Raivio, T., Cole, L.W., Plumer, L.W., Jacobson Dickman, E.E., Mellon, P.L., Zhou, Q.Y. and Crowley Jr., W.F. (2007) Loss of Function Mutation in the Prokineticin 2 Gene Causes Kallmann Syndromeand Normosmic Idiopathic Hypogonadotropic Hypogonadism. Proceedings of the National Academy of Sciences of the United States of America, 104, 17447-17452.

http://dx.doi.org/10.1073/pnas.0707173104

[13] Cole, L.W., Sidis, Y., Zhang, C., Quinton, R., Plummer, L., Pignarelli, D., Hughes, V.A., Dwyer, A.A, Raivio, T., Hayes, F.J., Seminara, S.B., Huot, C., Alos, N., Speiser, P., Takeshita, A., et al. (2008) Mutations in Prokineticin 2 and Prokinrticin Receptor 2 Genes in Human Gonadotropin-Releasing Hormone Deficiency, Molecular Genetics and Clinical Spectrum. Journal of Clinical Endocrinology \& Metabolism, 93, 3551-3559.

http://dx.doi.org/10.1210/jc.2007-2654 
[14] Leroy, C., Fouveaut, C., Leclercq, S., Jacquemont, S., Boullay, H.D., Lespinasse, J., Delpech, M., Dupont, J.M., Hardelin, J.P. and Dode, C. (2008) Biallelic Mutations in the Prokineticin Gene in Two Sporadic Case of of Kallmann Syndrome. European Journal of Human Genetics, 16, 865-868. http://dx.doi.org/10.1038/ejhg.2008.15

[15] Abreu, A.P., Trarbach, E.B., de Castro, M., Frade Costa, E.M., Versiani, B., Matias Baptista, M.T., Garmes, H.M., Mendonca, B.B. and Latronico, A.C. (2008) Loss of Function Mutations in the Genes Encoding Prokineticin 2 or Prokineticin Receptor 2 Cause Autosomal Recessive Kallmann Syndrome. Journal of Clinical Endocrinology \& Metabolism, 93, 41134118. http://dx.doi.org/10.1210/jc.2008-0958

[16] Sarfati, J., Guiochon-Mantel, A., Rondard, P., Arnulf, L., Garcio-Pinero, A., Wolczynski, S., Brailly-Tabard, S., Bidet, M., Ramos-Arroyo, M., Mathieu, M., Lienhardt-Roussie, A., Morgan, G., et al. (2010) Acomparative Phenotypic Study of Kallmann Syndrome Patients Carrying Monoallelic and Biallelic Mutations in the Prokineticin 2 or Prokineticin Receptor 2 Genes. Journal of Clinical Endocrinology \& Metabolism, 85, 659-669. http://dx.doi.org/10.1210/jc.2009-0843

[17] Ogata, T., Fujiwara, I., Ogawa, F., Sato, N., Udaka, T. and Kosaki, S. (2006) Kallmann Syndrome Phenotype in a Female Patient with CHARGE Syndrome and CHD7 Mutation. Endocrine Journal, 53, 741-743. http://dx.doi.org/10.1507/endocrj.K06-099

[18] Jongmans, M.C., van Ravenswaaij-Arts, C.M., Pitteloud, N., Ogata, T., Sato, N., Claahsen-van der Grinden, H.I., van-den Donk, K., Seminara, S., Bergman, J.E.H., Brunner, H.G., Crowley Jr., W.F. and Hoefsloot, L.H. (2009) CHD7 Mutations in Patients Initially Diagnosed with Kallmann Syndrome-The Clinical Overlap with CHARGE Syndrome. Clinical Genetics, 75, 65-71. http://dx.doi.org/10.1111/j.1399-0004.2008.01107.x

[19] Kim, H.G., Kurth, I., Lan, F., Meliciani, I., Wenzel, W., Fom, S.H., Kang, G.B., Rosenberger, G., Tekin, M., Okata, M., Bick, D.P., Sherins, T.J., Walker, S.I., Shi, Y., Gusella, J.F. and Layman, L.C. (2008) Mutations in CHD7, Encoding a Chromatin Remodeling Protein, Causes Idiopathic Hypogonadotropic Hypogonadism and Kallmann Syndrome. American Journal of Human Genetics, 83, 511-519. http://dx.doi.org/10.1016/j.ajhg.2008.09.005

[20] Kim, H.G., Ahnm J.W., Kurth, I., Ullmann, R., Kim, H.T., et al. (2010) WDR11: A WD Protein That Interacts with Transcription Factor EMX1, Is Mutated in Idiopathic Hypogonadotropic Hypogonadism and Kallmann Syndrome. American Journal of Human Genetics, 87, 465-479. http://dx.doi.org/10.1016/j.ajhg.2010.08.018

[21] Hanchate, N.K., Giacobini, P., Lhullier, P., Prakash, J., Espy, C., Fouveaut, C., et al. (2012) SEMA3A: A Gene Involved in Axonal Pathfinding, Is Mutated in Some Patients with Kallmann Syndrome. PLoS Gene, 8, e1002896. http://dx.doi.org/10.1371/journal.pgen.1002896

[22] Young, J., Metay, C., Bouligand, J., Tou, B., Francou, B., Maione, L., et al. (2012) SEMA3A Seletion in a Family with Kallmann Syndrome Validates the Role of Semaphoring 3A in Human Puberty and Olfactory System. Human Reproduction, 27, 1460-1465. http://dx.doi.org/10.1093/humrep/des022

[23] Cariboni, A., Davidson, K., Rakic, S., Maggi, R., Parnavelas, J.G. and Ruhrberg, C. (2011) Defective Gonadotropin Releasing Hormone Neuron Migration in Mice Lacking SEMA3A Signaling through NRP1 and NRP2: Implications for the Aetiology of Hypogonadotropic Hypogonadism. Human Molecular Genetics, 20, 336-344. http://dx.doi.org/10.1093/hmg/ddq468

[24] Kansakoski, J., Fagerholm, R., Laitinen, E.M., Vaaralahti, K., Hackman, P., Pitteloud, N., Raivio, T. and Tommisia, J. (2014) Mutation Screening of SEMA3A and SEMA7A in Patients with Congenital Hypogonadotropic Hypogonadism. Pediatric Research, 75, 641-644. http://dx.doi.org/10.1038/pr.2014.23 
[25] Balasubramaniam, R., Plummer, L., Sidis, Y., Pitteloud, N., Cecila, N., Zhou, Q.Y. and Crowley, Jr W.F. (2011) The Puzzles of the Pronineticin 2 Pathway in Human Reproduction. Molecular and Cellular Endocrinology, 346, 44-50.

http://dx.doi.org/10.1016/j.mce.2011.05.040

[26] Martin, C., Balasubramanium, R., Dwyer, A.A., Au, M.G., Sidis, Y., Kaiser, U.B., Seminara, S.B., Pitteloud, N., Zhou, Q.Y. and Crowley Jr W.F. (2011) The Role of the Prokineticin 2 Pathway in Human Teproduction: Evidence from the Study of Human and Murine Mutations. Endocrine Reviews, 32, 225-246. http://dx.doi.org/10.1210/er.2010-0007

[27] Kochar, Kaur, K., Allahbadia, G.N. and Singh, M. (2013) An Update on the Role of Prokineticins in Human Reproduction-Potential Therapeutic Applications. Open Journal of Genetics, 3, 201-215. http://dx.doi.org/10.4236/ojgen.2013.33023

[28] Dode, C. and Rondard, P. (2013) PROK2/PROKR2 Signaling and Kallmann Syndrome. Frontiers in Endocrinology (Lausanne), 4, 19. http://dx.doi.org/10.3389/fendo.2013.00019

[29] Ragancokoya, D., Rocca, E., Oonk, A.M.M., Schultz, H., Rohde, E., Bednarsch, J., Feenstra, I., Pennings, R.J., Wende, H. and Garratt, A.N. (2014) TSHZ1-Dependent Gene Regulation Is Essential for Olfactory Bulb Development and Olfaction. Journal of Clinical Investigation, 124, 1224-1227. http://dx.doi.org/10.1530/EJE-13-0419

[30] Sarfati, J., Fouveat, C., Leroy, C., Jeanpierre, M., Hardelin, J.P. and Dode, C. (2013) Greater Prevalence of PROKR2 Mutations in Kallmann Syndrome Patients from Maghreb than in European Patients. European Journal of Endocrinology, 169, 805-809. http://dx.doi.org/10.1530/EJE-13-0419

[31] Chen, D.N., Ma, Y.T., Liu, H., Ziou, Q.Y. and Li, J.D. (2014) Functional Rescue of Kallmann Syndrome-Associated PKR2 Receptor Mutants Deficient in Trafficking. Journal of Biological Chemistry, 289, 15518-15526. http://dx.doi.org/10.1074/jbc.M114.556381

[32] Salian-Mehta, S., Xu, M., Knox, A.J., Plummer, A.L., Slavov, D., Taylor, M., Bevers, S., Hodgers. R.S., Crowley Jr., W.F. and Wierman, M.E. (2014) Functional Consequences of AXL Sequence Variants in Hypogonadotropic Hypogonadism. Journal of Clinical Endocrinology \& Metabolism, 99, 1452-1460. http://dx.doi.org/10.1210/jc.2013-3426

[33] Newbern, K., Natrajan, N., Goo-Kim, H., Chorich, L.P., Halvorson, L.M., Cameron, R.S. and Layman, L.C. (2013) Identification of HESX1 Mutations in Kallmann Syndrome. Fertility and Sterility, 99, 1831-1837. http://dx.doi.org/10.1016/j.fertnstert.2013.01.149

[34] Niederberger, C. (2014) RE, Identification of HESX1 Mutations in Kallmanns Syndrome. Journal of Urology, 191, 1081. http://dx.doi.org/10.1016/j.juro.2014.01.067

[35] Hardelin, J.P. and Dode, C. (2008) The Complex Genetics of Kallmann Syndrome, KAL1, FGFR1, FGF8, PROKR2, PROK2, et al. Sexual Development, 2, 181-193. http://dx.doi.org/10.1159/000152034

[36] de Roux, N., Genin, E., Carel, J.C., Matsuda, F., CusSain, J.L. and Milgrom, E. (2003) Hypogonadotropic Hypogonadism Due to Loss of Function of the KiSS1 Derived Peptide Receptor GPR54. Proceedings of the National Academy of Sciences of the United States of America, 100, 10972-10976 http://dx.doi.org/10.1073/pnas.1834399100

[37] Pallais, J.C., Bo-Abbas, Y., Pitteloud, N., Crowley Jr., W. and FandSeminara, B. (2006) Neuroendocrine, Gonadal, Placental, and Obstetric Phenotypes in Patients with IHH and Mutations in the G-Protein Coupled Receptor, GPR54. Molecular and Cellular Endocrinology, 254-255, 70-77. http://dx.doi.org/10.1016/j.mce.2006.04.019

[38] Topaloglu, A.K., Tello, J.A., Kotan, L.D., Ozbek, M.N., Yilmaz, M.B., Erdogan, S., Gurbuz, F., Terniz, F., Millar, R.P. and Yuksel, B. (2012) Inactivating KISS1 Mutationsand Hypogonadotropic Hypogonadism. The New England Journal of Medicine, 366, 629-635. 
http://dx.doi.org/10.1056/NEJMoa1111184

[39] Topaloglu, A.K., Reimann, F., Guclu, M., Yalin, A.S., Kotani, L.D., Porter, K.M.Serin, A,Mungan, N.O,Cook, J.R,Ozbek, M.N,Imamoglu, S, Akalin, N.S., et al. (2009) TAC3 and TACR3 Mutations in Familial Hypogonadotropic Hypogonadism Reveal a Key Role for Neurokinin B in the Central Control of Reproduction. Nature Genetics, 41, 354-358. http://dx.doi.org/10.1038/ng.306

[40] Bouligard, J., Ghervan, C., Tello, J.A., Brailly-Tabard, S., Salenave, S., Chanson, P., Lombes, P., Millar, R.P., Guiochon-Mantel, A. and Young, J. (2009) Isolated Familial Hypogonadotropic Hypogonadism ana a GnRH 1 Mutation. The New England Journal of Medicine, 360, 2742-2748. http://dx.doi.org/10.1056/NEJMoa0900136

[41] Chan, Y.M., de Guillebon, A., Lang-Muritano, M., Plummer, L., Cerrato, F., Tsiaras, F., Gaspert, A., Lavoie, H.B., Wu, C.H., Ceowley Jr., W.F., Amory, J.K., Pitteloud, N., Seminara, S.B. and Gn, R.H. (2009) 1 Mutations in Patients with Idiopathic Hypogonaditropic Hypogonadism. Proceedings of the National Academy of Sciences of the United States of America, 106, 11703-11708. http://dx.doi.org/10.1073/pnas.0903449106

[42] Tello, J.A., Newton, C.L., Bouligard, J., Guiochon-Mantel, A., Millar, R.P. and Young, J. (2012) Congenital Hypogonadotropic Hypogonadism Due to GnRH Receptor Mutations in Three Brothers Reveal Sires Affecting Conformation and Coupling. PLoS ONE, 7, e38456. http://dx.doi.org/10.1371/journal.pone.0038456

[43] Sykiotis, G.P., Plummer, L., Hughes, V.A., Au, M., Durrani, S., Young, S.N., Dwyer, A.A., Quinton, R., Hall, J.E., Gusella, J.F., Seminara, S.B., Crowley Jr., W.F. and Pitteloud, N. (2010) Oligogenic Basis of Isolated Gonadotropin-Releasing Hormone Deficiency. Proceedings of the National Academy of Sciences of the United States of America, 107, 1514015144. http://dx.doi.org/10.1073/pnas.1009622107

[44] Lewkowitz-Shupntoff, H.M., Hughes, V.A., Plummer, L., Au, M.G., Doty, R.L., Seminara, S.B., Chan, Y.M., Potteloud, N., Crowley Jr., W.F. and Balasubramaniam, R. (2012) Olfactory, Phenotypic Spectrums in Idiopathic Hypogonadotropic Hypogonadism, Pathophysiological and Genetic Implications. Journal of Clinical Endocrinology \& Metabolism, 97, E136-E144. http://dx.doi.org/10.1210/jc.2011-2041

[45] Valetti, E.D., Vazzat, S., Rochira, V., Granata, A., Madeo Genovesic, M., Pignatti, E., Marino, M., Carani, C. and Simon, M. (2013) Prevalence of Olfactory and Other Developmental Anomalies in Patients with Central Hypogonadotropic Hupogonadism. Frontiers in Endocrinology (Laussanne), 4, 70.

[46] Plana, A.M., Villanueva, C., Laccourreye, O., Bonfils, P. and de Roux, N. (2013) PROKR2 and PROK2 Mutations Cause Isolated Congenital Anosmia without Gonadotropin Deficiency. European Journal of Endocrinology, 168, 31-37. http://dx.doi.org/10.1530/EJE-12-0578

[47] Qyanor, S.D., Kim, G.H., Cappello, E.H., Williams, T., Chorich, L.P., Bick, D.P., Sherins, R.J. and Laymans, L.C. (2011) The Prevalence of Digenic Mutations in Patients with Normosmic Hypogonadotropic Hypogonadism and Kalmmann Syndrome. Fertility and Sterility, 96, 1424-30e6

[48] Chung, W.C., Moyle, S.S. and Tsai, P.S. (2008) Fibroblast Growth Factor 8 Signaling through Fibroblast Growth Factor Receptor 1 Is Required for the Emergence of Gonadotropin Releasing Hormone Neurons. Endocrinology, 149, 4997-5003.

http://dx.doi.org/10.1210/en.2007-1634

[49] Ladher, R.K., Weight, T.J., Moon, A.M., Mansour, S.A. and Schoenwolf, G.C. (2005) FGF8 Initiares Inner Ear Induction in Chick and Mouse. Genes \& Development, 19, 603-615. http://dx.doi.org/10.1101/gad.1273605 
[50] Martinez-Morales, J.R., Del Bene, F., Nica, G., Hammerschmidt, M., Bovolenta, P. and Willbrodt, J. (2005) Differentiation of the Vertebrate Retina Is Coordinated by an FGF Signaling Center. Developmental Cell, 8, 565-574.

http://dx.doi.org/10.1016/j.devcel.2005.01.022

[51] Perantoni, A.O., Timofeeva, O., Naillat, F., Richman, C., Pajni-Underwood, S., Wilson, C., Vainio, S., Dove, L.F. and Lewandoski, M. (2005) Inactivation of FGF8 in Early Mesoderm Reveals an Essential Role in Kidney Development. Development, 132, 3859-3871. http://dx.doi.org/10.1242/dev.01945

[52] Lewandoski, M., Sun, X. and Martin, G.R. (2000) FGF8 Signaling from the AER Is Essential for Normal Limb Development. Nature Genetics, 26, 460-463. http://dx.doi.org/10.1038/82609

[53] Miraoui, H., Dwyer, A. and Pitteloud, N. (2011) Role of Fibroblast Growth Factor (FGF) Signaling in the Neuroendocrine Control of Human Reptoduction. Molecular and Cellular Endocrinology, 346, 37-43. http://dx.doi.org/10.1016/j.mce.2011.05.042

[54] Tornberg, J., Sykiotis, G.P., Keefe, K., Plummer, L., Hoang, X., Hall, J.E., Quinton, R., etal. (2011) Heparan sulfate 6-O-Transferase 1: A Gene Involved in Extracellular Sugar Modifications Is Mutated in Patients with Idiopathic Hypogonadsotropic Hypogonadism. Proceedings of the National Academy of Sciences of the United States of America, 108, 11524-11529. http://dx.doi.org/10.1073/pnas.1102284108

[55] Miraoui, H., Dwyer, A.A., Sykiotis, G.P., Plummer, L., Chung, W., Feng, B., Beenken, A., Clarke, J., Pers, T.H., Dworzynski, P., Keefe, K., Niedziela, M., Raivio, T., Crowlry, W.T., Seminara, S.B., Quinton, R., Hughes, V.A., Kumanov, P., Young, J., Yialamas, M.A., Hall, J.E., van-Vliet, G., Chanoine, J.P., Rubenstein, J., Mohammadi, M., Tsai, P.S., Sidis, Y., Lage, K. and Pitteloud, N. (2013) Mutations in FGF17, IL17RD, DUSP6, SPRY4 and FLRT3 Are Iudentifird in Indiciduals wirh Congenital Hypogonadotropic Hypogonadism. American Journal of Human Genetics, 92, 725-743. http://dx.doi.org/10.1016/j.ajhg.2013.04.008

[56] Abhazonov, A., Tabin, C.J. (2004) Shh and FGF8 Act Synergistically to Drive Cartlage Outgrowth during Cranial Development. Developmental Biology, 273, 134-148. http://dx.doi.org/10.1016/j.ydbio.2004.05.028

[57] Bajpai, R., Chen, D.A., Rada-Iglesia, A., Zhang, J., Xiong, Y., Helins, J., Chang, C.P., Zhao, Y. and Swigut, T. and Wysocka, J. (2010) CHD7 Cooperates with PBAF to Control Multipotent Neural Crest Formation. Nature, 463, 958-962. http://dx.doi.org/10.1038/nature08733

[58] Creuzet, S., Schuler, B., Couly, G. and LeDouarin, N.M. (2004) Reciprocal Relationship between FGF8 and Neural Crest Cells in Fascial and Forebrain Development. Proceedings of the National Academy of Sciences of the United States of America, 101, 1843-1847. http://dx.doi.org/10.1073/pnas.0400869101

[59] Kawauchi, S., Shou, J., Santos Hebert, J.M., McConell, S.K., Mason, I. and Calof, A.L. (2005) FGF8 Expression Defines Amorphogenetic Center Required for Olfactory Neurogenesis Ans Nasal Cavity Development in the Mouse. Development, 132, 5211-5223. http://dx.doi.org/10.1242/dev.02143

[60] Trarbach, E.B., Abreu, A.P., Silveira, L.F., Garmes, H.M., Baptista, M.T., Teles, M.G., Costa, E.M., Mohammadi, M., Pitelloud, N., Mendonca, B.B. and Letronico, A.C. (2010) Nonsense Mutations in FGF8 Gene Causing Different Degrees of Human Gonadotropin-Releasing Deficiency. Journal of Clinical Endocrinology \& Metabolism, 95, 3491-3496. http://dx.doi.org/10.1210/jc.2010-0176

[61] Forni, P.E., Burds, C.T., Melvin, V.S., Williams, T. and Wray, S. (2011) Neural Crest and Ectodermal Cells Intermix in the Nasal Placode to Give Rise to GnRH-1 Neurons, Sensory 
Neurons and Olfactory Ensheathing Cells. The Journal of Neuroscience, 31, 6915-6927. http://dx.doi.org/10.1523/JNEUROSCI.6087-10.2011

[62] Carter, L.A., Macdonald, J.L. and Roskams, A.J. (2004) Olfactory Horizontal Basal Cells Demonstrate a Conserved Multipotent Progenitor Phenotype. The Journal of Neuroscience, 24, 5670-5683. http://dx.doi.org/10.1523/JNEUROSCI.0330-04.2004

[63] Williams, M.S. (2005) Speculations on the Pathogenesis of CHARGE Syndrome. American Journal of Medical Genetics Part A, 133A, 318-325. http://dx.doi.org/10.1002/ajmg.a.30561

[64] Forni, P.E., Bharti, K., Flannery, E.M., Shimogori, T. and Wray, S. (2013) The Indirect Role of Fibroblast Growth Factor-8 in Defining Neurogenic Niches of the Olfactory/GnRH Systems. The Journal of Neuroscience, 33, 19620-19634. http://dx.doi.org/10.1523/JNEUROSCI.3238-13.2013

[65] Schultz, Y., Wehner, P., Opitz, L., Salinas-Riester, G., Bongers, E.M., van Ravenswaaij-Arts, C.M., Wincent, J., Schoumans, J., Kohlhase, J., Borchers, A. and Pauli, S. (2014) CHD7, the Gene Mutated in CHARGE Syndrome: Regulates Genes Involved in Neural Crest Cell Guidance. Human Genetics, 133, 997-1009. http://dx.doi.org/10.1007/s00439-014-1444-2

[66] Costa-Barbosa, F.A., Balasubramaniam, R., Keefe, K.W., Shaw, N.D., Al-Tassan, N., Plummer, L., Dwyer, A.A., Buck, C.L., Choi, C.H., Seminara, D.B., Quinton, R., Monies, D., Meyer, D., Hall, J.E., Pitteloud, N. and Crowley Jr., W.F. (2013) Prioritizing Geneting Testing in Patients with Kallmann Syndrome Using Clinical Phenotypes. Journal of Clinical Endocrinology \& Metabolism, 98, E943-E953. http://dx.doi.org/10.1210/jc.2012-4116

[67] Dode, C. and Hardelin, P. (2010) Clinical Genetics of Kallmanns Syndrome. Annales d Endocrinologie (Paris), 71, 149-157. http://dx.doi.org/10.1016/j.ando.2010.02.005

[68] Fideleff, H.L., Bouquete, H.R., Suarez, M.G. and Azaretzky, M. (2009) Prolactinomas in Children and Adolescents. Hormone Research, 72, 197-205. http://dx.doi.org/10.1159/000236081

[69] Jagabbathan, J., Dumont, A.S. and Jane Jr., J.A. (2006) Diagnosis and Management of Pediatric Sellar Lrsions. Frontiers of Hormone Research, 34, 83-104. http://dx.doi.org/10.1159/000091574

[70] Young, J. (2007) Endocrine Consequences of Haemochromatosis. Presse Médicale, 36, 1319-1325. http://dx.doi.org/10.1016/j.lpm.2007.01.041

[71] Ozgor, B. andSelimodiu, M.A. (2010) Coeliac Disease and Reproductive Disorders. Scandinavian Journal of Gastroenterology, 45, 395-402. http://dx.doi.org/10.3109/00365520903508902

[72] Farooqo, J.S., Wangensteen, T., Collins, S., Kimber, W., Matarese, G., Keoh, G.M., Lank, E., Moottommlev, B., Lopez-Fernandez, J., Ferraz-Amaro, I., Dattani, M.T., Ercan, O., Mvhre, A.G., Retterstol, L., Stanhoe, R., Edoe, J.A., McKenzie Undlien, D.E. and O'Rahilly, S. (2007) Clinical and Molecular Genetic Spectrum of Genetic Spectrum of Congenital Deficiency of the Leptin Receptor. The New England Journal of Medicine, 356, 237-247. http://dx.doi.org/10.1056/NEJMoa063988

[73] Lin, L., Gu, W.X., Ozisik, G., To, W.S., Owen, C.J., Jameson, J.L. and Achermann, J.C. (2006) Analysis of DAX 1 (NROB1) and steroidogenic Factor 1 (SF1/Ad4BP, NR5A1) in Children and Adults with Primary Adrenal Failure: Ten Years of Experience. Journal of Clinical Endocrinology \& Metabolism, 91, 3048-3054.

http://dx.doi.org/10.1210/jc.2006-0603

[74] Netchine, I., Sobrier, M.L., Krude, H., Schnabel, D., Maohne, M., Marcos, E., Duriez, B., Cacheux, V., Moers, A., Grossns, M., Gruters, A. and Amselem, S. (2000) Mutations in 
LHX3 Result in a New Syndrome Revealed by Combined Pituitary Hormone Deficiency. Nature Genetics, 25, 182-186. http://dx.doi.org/10.1038/76041

[75] Pinto, G., Abadie, V., Mesnade, R., Blustain, J., Cabrol, S., Amiel, J., Hertz-Pennier, L., Bertrand, A.M., Lyonnet, S., Rappaport, E. and Netchine, I. (2005) CHARGE Syndrome Includes Hypogonadotropic Hypogonadism and Abnormal Olfactory Bulb Development. Journal of Clinical Endocrinology \& Metabolism, 90, 5621-5626. http://dx.doi.org/10.1210/jc.2004-2474

[76] Rottembouro, D., Linglart, A., Adamsbaum, C., Lahlou, N., Teinturier, C., Bougneres, P. and Carel, J.C. (2008) Gonadotrophic Status in Adolescent s with Pituitary Stalk Interruption Syndrome. Clinical Endocrinology, 69, 105-111.

http://dx.doi.org/10.1111/j.1365-2265.2007.03155.x

[77] Revnaud, R., Gueydan, M., Saveanu, A., Vallette-Ksic, S., Enjalbert, A., Beue, T. and Barlier, A. (2006) Genetic Screening of Combined Pituitary Hormone Deficiency Experience in 195 Patients. Journal of Clinical Endocrinology \& Metabolism, 91, 3329-3336. http://dx.doi.org/10.1210/jc.2005-2173

[78] Harrington, J. and Palmert, M.R. (2012) Clinical Review, Distinguishing Constitutional Delay of Growrh and Puberty from Isolated Hypogonadotropic Hypogonadism, Crotical Appraisal of Available Diagnostic Tests. Journal of Clinical Endocrinology \& Metabolism, 97, 3056-3067. http://dx.doi.org/10.1210/jc.2012-1598

[79] Sedimeyer, I.L. and Palmert, M.R. (2002) Delayed Puberty: Analysis of a Large Case Series from an Academic Center. Journal of Clinical Endocrinology \& Metabolism, 87, 1613-1620. http://dx.doi.org/10.1210/jcem.87.4.8395

[80] Pitteloud, N., Hayes, F.J., Boeoole, P.A., DeCruz, S., Seminara, S.B., McLaughlin, D.T. and Crowley Jr., W.F. (2002) The Role of Prior Pubertal Development, Biochemical Markers of Testicular Maturation and Genetics in Elucidating the Phenotypic Herterogeneity of Idiopathic hypogonadotrophic hypogonadism. Journal of Clinical Endocrinology \& Metabolism, 87, 152-160. http://dx.doi.org/10.1210/jcem.87.1.8131

[81] Salenave, S., Chandon, P., Bry, H., Pugeat, M., Cabrol, S., Murat, A., Lecomte, P., Braiily, S., Hardelin, J.P., Dode, C. and Young, J. (2008) Kallmann's Syndrome: A Comparison of the Reproductive Phenotypes in Men Carrying KAL1 and FGR1/KAL2 Mutations. Journal of Clinical Endocrinology \& Metabolism, 93, 758-763. http://dx.doi.org/10.1210/jc.2007-1168

[82] Coutant, R., Biette-Demrneix, E., Bouvattier, C., Bouhours-Nouet, N., Gatelais, F., Dufresne, S., Rouleau, S. and Lahlou, N. (2010) Baseline Inhibin B and Anti Mullerian Hormone Measurements for Diagnosis of Hypogonadotropic Hypogonadism in Boyswith Delayed Puberty. Journal of Clinical Endocrinology \& Metaboism, 95, 5225-5232. http://dx.doi.org/10.1210/jc.2010-1535

[83] De Luca, F., Argente, J., Cavallo, L., Ceowne, E., Delemarre-Vande Waal, HA., De Sanctis, C., Di Maio, S., Noriavaara, E., Oostdjik, W., Severi, F., ToninI, G., Trifiro, G., Voorhoeve, P.G. and Wu, F. (2001) Management of Puberty in Constitutional Dalay of Growth and Puberty. International workshop on Management of Puberty for Optimum Auxological Results, Journal of Pediatrics, 14, 953-957.

[84] Young, J. (2012) Approach to the Male Patient with Congenital Hypogonadotropic Hypogonadism. Journal of Clinical Endocrinology \& Metabolism, 97, 707-718. http://dx.doi.org/10.1210/jc.2011-1664

[85] Manara, R., Salvalaggio, A., Favaro, A., Palumbo, V., Citton, V., Elefante, A., Brunetti, A., Di Salle, F., Bonarini, G. and Sinisi, A.A. and Kallmann Syndrome Neuroradiological Study Group (2014) Brain Changes in Kallmann Syndrome. American Journal of Neuroradiology, 35, 1700-1706. http://dx.doi.org/10.3174/ajnr.A3946 
[86] Chew, S., Balasubramaniam, R., Chan, W.M., Kang, P.B., Andrews, C., Webb, B.D., Mackinson, S.E., Oystrreck, D.T., Rankin, J., Crawford, T.O., Geraghty, M., Pomeroy, S.L., Crowlryt Jr., W.F., Jabs, E.W., Hunter, D.G., Grant, P.E. and Engle, E.C. (2013) A Novel Syndrome Caused by the E410K Amino acid Substitution in the Neuronal $\beta$-Tubulin Isotype 3. Brain, 136, 522-535. http://dx.doi.org/10.1093/brain/aws345

[87] Raivio, T., Avbeli, M., McCabe, M.J., Romero, D.J., Swyer, A.A., Tommiska, J., Sykiotis, G.P., Gregory, I.C., Diaczok, D., Tziaferi, V., Elting, M.W., Padidela, M.W., Plummer, L., Martin, C., Feng, B., Zhang, C., Zhou, Q.Y., Chen, H., Mohammedi, M., Quinton, R., Sidis, Y., Radovick, S., Dattani, M.T. and Pitelloud, N. (2012) Genetic Overlap in Kallmann Syndrome, Combined Pituitary Hormone Deficiency, and Septo Optic Dysplasia. Journal of Clinical Endocrinology \& Metabolism, 97, E694-E699.

http://dx.doi.org/10.1210/jc.2011-2938

[88] McCabe, M.J., Gaston-Massuet, C., Gregory, L.C., Alatzoglu, K.S., Tziaferi, V., Sbai, O., Rondard, P., Masumoto, K.H., Nagano, M., Shigeyoshi, Y., Pfiefer, M., Hulse, T., Buchanan, C.R., Potteloud, N., Martinez-Barbera, J.P. and Dattani, M.T. (2013) Variations in PROKR2 but Not PROK2, Are Associated with Hypopituitarism and Septo-Optic Dysplasia. Journal of Clinical Endocrinology \& Metabolism, 98, E547-E557.

http://dx.doi.org/10.1210/jc.2012-3067

[89] McCabe, M.J., Alatzoglu, K.S. and Dattani, M.T. (2011) Septo-Optic Dysplasia and Other Midline Defects: The Role of Transcription Factors, HESX1 and beyond. Best Practice \& Research Clinical Endocrinology \& Metabolism, 25, 115-124. http://dx.doi.org/10.1016/j.beem.2010.06.008

[90] Cohen Jr., M.M. (2006) Holoprosencephaly, Clinical, Anatomic, and Molecular Dimensions. Birth Defects Research Part A: Clinical and Molecular Teratology, 76, 658-673. http://dx.doi.org/10.1002/bdra.20295

[91] Dubourg, C., Teixeira, L., Levilliers, J., Fouveaut, C., Bouchard, P., et al. (2007) Holoprosencephaly. Orphanet Journal of Rare Diseases, 2, 8.

http://dx.doi.org/10.1186/1750-1172-2-8

[92] Vaaralahti, K., Raivio, T., Koivu, R., Valanne, L., Laitinen, M. and Tommiska, J. (2012) Genetic Overlap between holoprosencephaly and Kallmann Syndrome. Molecular Syndromology, 3, 1-5. http://dx.doi.org/10.1159/000338706

[93] Castaneyra-Perdono, A., Casraneyra-Ruiz, L., Gonzalez-Marrero, I., Castaneyra-Ruiz, A., GonzalezoToledo, J.M., Castaneyra-Ruiz, M. and Carmona-Calero, E.M. (2014) Early Treatment of Kallmann Syndrome Mayorevent Eunuchoid Appearance and Behavior. Medical Hypotheses, 82, 74-76. http://dx.doi.org/10.1016/j.mehy.2013.11.011

[94] Hoffman, A.R. and Crowley Jr., W.F. (1982) Induction of Puberty in Men by Long-Term Pulsatlle Administration of Low Dose Gonadotropin Releasing Hormone. The New England Journal of Medicine, 307, 1237-1241. http://dx.doi.org/10.1056/NEJM198211113072003

[95] Raivio, T., Wikstrom, M. and Dunkel, L. (2007) Treatment of Gonadotropin Deficient Boys with Recombinant Human FSH, Long Term Observation and Outcome. European Journal of Endocrinology, 156, 105-111. http://dx.doi.org/10.1530/eje.1.02315

[96] Quinton, R., Cheow, H.K., Tymms, D.J., Bouloux, P.M., Wu, F.C. and Jacobs, H.C. (1999) Kallmann's Syndrome: Is It Always for life? Clinical Endocrinology, 50, 481-485. http://dx.doi.org/10.1046/j.1365-2265.1999.00708.x

[97] Raivio, T., Falardeau, J., Dwyer, A., Quinton, R., Hayes, F.J., Hughes, V.A., Cole, L.W., Pearce, S.H., Lee, H., Boepple, P., Crowley Jr., W.F. and Pitteliud, N. (2007) Reversal of Idiopathic Hypogonadotropic Hypogonadism. The New England Journal of Medicine, 357, 
863-873. http://dx.doi.org/10.1056/NEJMoa066494

[98] Sidhoum, V.F., Chan, Y.M., Lipincott, M.F., Balasubramaniam, R., Quinton R., Plummel, L., Dwyer, A., Pitelloud, N., Hayes, F.J., Martin, K.A., Boepple, P.A. and Seminara, S.B. (2013) Reversal and Relapse of Hypogonadotropic Hypogonadism, Resilience and Fragility of the Reproductive Neuroendocrine System. Journal of Clinical Endocrinology \& Metabolism, 99, 861-870. http://dx.doi.org/10.1210/jc.2013-2809

[99] Bouvattier, C., Tauber, M., Jouret, B., Chaussan, J.L. and Rochiccioli, P. (1999) Gonadotropic Treatment of Hypogonadotropic Hypogonadal Adolescents. Journal of Pediatric Endocrinology and Metabolism, 12, 339-344.

[100] Gong, W. and Gao, X.C. (2013) Clinical Diagnosis and Treatment of Male Kallmann Syndrome. National Journal of Andrology, 19, 1111-1114.

[101] Pitelloud, N., Hayes, F.J., Boepple, P.A., Lee, H. and Crowley Jr., W.F. (2002) Predictors of Outcome of Longterm GnRH Therapy in men with Idiopathic Hypogonadotropic Hypogonadism. Journal of Clinical Endocrinology \& Metabo-ism, 87, 4128-4141. http://dx.doi.org/10.1210/jc.2002-020518

[102] Sykiotis, G.P., Hoang, X.H., Avberg, M., Hayes, F.J., Thambundit, A., Dwyer, A., Au, M., Plummer, L., Crowley Jr., W.F. and Pitelloud, N. (2010) Congenital Idiopathic Hypogonadotropic Hypogonadism: Evidence and Defects of the Hypothalamus, Pituitary, and Testis. Journal of Clinical Endocrinology \& Metabolism, 95, 3019-3027. http://dx.doi.org/10.1210/jc.2009-2582

[103] Sinisi, A.A., Asci, R., Bellastella, G., Maione, L., Esposito, D., Elefante, A., DeBellis, A., Bellastella, A. and Iolascon, A. (2008) Homozygous Miutation in the Prokineticin Receptor 2 Gene (Val 274Asp) presenting as Reversible Kallmann Syndrome and Persistent Oligozoospermia: Case Report. Human Reproduction, 23, 2380-2384. http://dx.doi.org/10.1093/humrep/den247

[104] Dwyer, A.A., Sykiotis, G.P., Hayes, F.J., Boepple, P.A., Lee, H., Loughlin, K.R., Dym, M., Sluss, P.M., Crowley Jr., W.F. and Pitelloud, N. (2013) Trial of Recombinant Follicle-Stimulating Hormone Pretreatment in Patients with Congenital Hypogonadotropic Hypogonadism. Journal of Clinical Endocrinology \& Metabolism, 98, E1790-E1795. http://dx.doi.org/10.1210/jc.2013-2518

[105] Pitelloud, N., Thambundit, A., Dwyer, A.A., Falardeau, J.L., Plummer, L., Caronia, L.M., Hayes, F.J., Lee, H., Boepple, P.A. and Crowley Jr., W.F. (2009) Role of Seminiferous Tubular Development in Determining the FSH vs LH Responsiveness to GnRH in Early Sexual Maturation. Neuroendocrinology, 90, 260-268. http://dx.doi.org/10.1159/000245383

[106] Trabados, S., Maione, L., Bry-Gauillard, H., Affres, H., Salenave, S., Sarfati, J., Bouvattier, C., Delemer, B., Chapson, P., Le Bouc, Y., Brailly-Tabard, S. and Young, J. (2014) Insulin-Like Peptide-3 (INSL-3) in Men with Congenital Hypogonadotropic Hypogonadism/Kallmann Syndrome and Effects of Different Modalities of Hormonal Treatment, Asingle-Center Study of 281 Patients. Journal of Clinical Endocrinology \& Metabolism, 99, E266-E275.

[107] Trabados, S., Lamothe, S., Maione, L., BouvaTtier, C., Sarfati, J., Brailly-Tabard, S. and Young, J. (2014) Congenital Hypogonadotropic Hypogonadism and Kallmann Syndrome as Models for Studying Hormonal Regulation of Human Testicular Endocrine Functions. Annales d Endocrinologie, 75, 79-87. http://dx.doi.org/10.1016/j.ando.2014.04.011

[108] Shaw, N.D., Seminara, S.B., Welt, C.K., Au, M.G., Plummer, L., Hughes, V.A., Dwyer, A.A., Martin, K.A., Quinton, R., Mericq, V., Merino, P.M., Gusella, J.F., Crowley Jr., W.F., Pitelloud, N. and Hall, J.E. (2011) Expanding the Phenotype and Genotype of Female GnRH Deficiency. Journal of Clinical Endocrinology \& Metabolism, 96, E566-E576.

http://dx.doi.org/10.1210/jc.2010-2292 
[109] Pallais, J.C., Au, M., Pitelloud, N., et al. (2011) Kallmann Syndrome. GeneReviews, Online. http://wwwnchnih

[110] Bramswig, J., Fabregues, F., Carmona, F., et al. (2009) Disorders of Pubertal Development. Deutsches Ärzteblatt International, 106, 295-303.

[111] Tsimaris, T., Vrachnis, N., Hiodromaiti, Z., et al. (2012) Long Term Follow up of Adolescent and Young Females with Hypetgonadotropic Hypogonadotropism. International Journal of Endocrinology, 73, 2367-2373.

[112] Hoffman, J., Watzlawik, M. and Richter-Appelt, H. (2013) Living with Kallmann Syndrome-Analysis of Subjective Expeerience Reports from Women. Geburtshilfe Frauenheilkd, 73, 111-120.

[113] Messinis, I.E. (2005) Ovulation Induction: A Mini Review. Human Reproduction, 20, 2688-2697. http://dx.doi.org/10.1093/humrep/dei128

[114] Knobil, E., Plant, T.M, Wildt, L., Belchetz, P.E. and Marshall, G. (1980) Controlof the Rhesus Monkey Menstrual Cycle, Permissive Role of Hypothalamic Gonadotrophic Gonsdotropin Releasing Hormone. Science, 207, 1371-1373. http://dx.doi.org/10.1126/science.6766566

[115] Belchetz, E., Plant, T.M., Nakai, Y., Keogh, E.J. and Knobil, E. (1978) Hypophyseal Responses to Continuous and Intermittent Delivery of Hypothalamic Gondotropin Releasing Hormone. Science, 212, 631-633. http://dx.doi.org/10.1126/science.100883

[116] Balasch, C., Salvatori, M., Regnani, G., et al. (2009) Ovarian Luteinizing Hormone Priming Preceding Follicle Stimulating Hormone Stimulation, Clinical and Endocrine Effects in Women with Long Term Hypogonadotropic Hypogonadism. Journal of Clinical Endocrinology \& Metabolism, 73, 2367-2373. http://dx.doi.org/10.1210/jc.2009-0262

[117] Abel, B.S., Shaw, N.D., Brown, J.M., Adams, J.M., Alati, T., Martin, K.A., Pitelloud, N., Seminara, S.B., Plummer, L., Pignatelli, D., Crowley Jr., W.F., Welt, C.K. and Hall, J.E. (2013) Responsiveness to a Physiological Regimen of GnRH Therapy and Relation to Gentype in Women with Isolated Hypogonadotropic Hypogonadism. Journal of Clinical Endocrinology \& Metabolism, 98, E206-E216. http://dx.doi.org/10.1210/jc.2012-3294

[118] Bouvattier, C., Maione, L., Bouligard, J., Dode, C., Guiochon-Mantel, A. and Young, J. (2011) Neonatal Gonadotropin Therapy in Male Congenital Hypogonadotropic Hypogonadism. Nature Reviews Endocrinology, 8, 172-182.

http://dx.doi.org/10.1038/nrendo.2011.164

[119] Main, K.M., Schmidt, I.M. and Skakkeberk, N.E. (2002) Early Postnatal Treatment of Hypogonaditropic Hypogonadism with Recombinant Human FSH and LH. European Journal of Endocrinology, 146, 75-79. http://dx.doi.org/10.1530/eje.0.1460075

[120] Main, K.M., Schmidt, I.M. and Skakkeberk, N.E. (2000) Apossible Role for Reproductive Hormones in Newborn Boys, Progressive Hypogonadism without the Postnatal Testosterone Peak. Journal of Clinical Endocrinology \& Metabolism, 85, 4905-4907. http://dx.doi.org/10.1210/jcem.85.12.7058

[121] Bouoneres, P., Francois, M., Pantalone, L., Rodrique, D., Bouvattier, C., Demesteere, E., Roger, D. and Lahlou, N. (2008) Effects of an Early Postnatal Treatment of Hypogonaditropic Hypogonadism with a Continuous Subcutaneous Infusion of Recombinant Follicle Stimulating Hormone and Luteinizing Hormone. Journal of Clinical Endocrinology \& Metabolism, 93, 2202-2205. http://dx.doi.org/10.1210/jc.2008-0121

[122] Trabados, S., Maione, L., Salenave, S., Baron, S., Gallarnd, F., Bry-Gauillard, H., Guiochon-Mantel, A., Chanson, P., Pitteloud, N., Sinisi, A.A., Brailly-Tabard, S. and Young, J. (2011) Estradiol Levels in Men with Congenial Hypogonadotropic Hypogonadism and the 
Effects of Different Modalities OF Different Treatment. Fertility and Sterility, 95, 23242329. http://dx.doi.org/10.1016/j.fertnstert.2011.03.091

[123] Gennari, L., Nuti, R. and Bilezikian, J.P. (2004) Aromatase Activity and Bone Homeostasis in Men. Journal of Clinical Endocrinology \& Metabolism, 89, 5898-5907. http://dx.doi.org/10.1210/jc.2004-1717

[124] Khosla, S., Amin, S. and Orwoll, E. (2008) Ostroporosis in Men. Endocrine Reviews, 29, 441-464. http://dx.doi.org/10.1210/er.2008-0002

[125] Khosla, S. (2010) Update in Male Osteoporosis Osteoporosis. Journal of Clinical Endocrinology \& Metabolism, 95, 3-10. http://dx.doi.org/10.1210/jc.2009-1740

[126] Kochar Kaur, K., Allahbadia, G.N. and Singh, M. (2014) Male Hypogonadism-Areview of Secondary Hypogonadism with Special Emphasis on Hypogonadotropic Hypogonadism. Journal of Endocrinology, Diabetes \& Obesity, 2, 1023.

[127] Rochira, V., Zirilli, L., Maffei, L., Fremrou, V., Ananda, C., Baldi, M., Ghigo, E., Aomaretti, G., Carani, C. and Lanfranco, F. (2010) Tall Stature without Growth Hormone, Four Male Patients with Aromatase Deficiency. Journal of Clinical Endocrinology \& Metabolism, 95, 1626-1633. http://dx.doi.org/10.1210/jc.2009-1743

[128] Pitteloud, N., Dwyer, A.A., DeCruz, S., Lee, H., Boepple, P.A., Crowley Jr., W.F. and Hayes, F.J. (2008) Inhibition of Luteinizing Hormone Secretion by Testosterone in Men Requires Aromatizarion for Its Pituitary but Not Its Hypothalamis Effects, Evidence from Tandem Study of Normal and Gonadotropin-Releasing Hormone Deficient Men. Journal of Clinical Endocrinology \& Metabolism, 93, 784-791. http://dx.doi.org/10.1210/jc.2007-2156

[129] George, J.T., Veldhius, J.D., Roseweir, A.K., Newton, C.L., Fasccenda, E., Millar, R.P. and Anderson, R.A. (2011) Kisspeptin 10 Is a Potent Stimulator of LH \& Increase Pulse Frequencty in Men. Journal of Clinical Endocrinology \& Metabolism, 96, E1228-E1236. http://dx.doi.org/10.1210/jc.2011-0089

[130] Kochar Kaur, K., Allahbadia, G.N. and Singh, M. (2012) Kisspeptins in Human Reproduction-Future Therapeutic Potentials. Journal of Assisted Reproduction and Genetics, 29, 999-1011. http://dx.doi.org/10.1007/s10815-012-9856-1

[131] Jayasena, C.N., Comninos, A.N., DeSilva, A., Abbara, A., Veldhius, J.D., Nijher, J.M., Gniyu-Dada, Z., Vaal, M., Stamp, G., Ghatel, M.A., Bloom, S.R. and Dhillo, W.S. (2013) Effects of Neurokinin B Administration on Reproductive Hormone Secretion in Healthy Men and Women. Journal of Clinical Endocrinology \& Metabolism, 99, E19-E27. http://dx.doi.org/10.1210/jc.2012-2880

[132] George, J.T. and Seminara, S.B. (2012) Kisspeptin and the Hypothamic Control of Reproduction, Lessons from the Human. Endocrinology, 153, 5130-5136. http://dx.doi.org/10.1210/en.2012-1429

[133] Young, J., George, J.T., Tello, J.A., Francou, B., Bouligard, J., Guiochon-Mauld, A., Brailly-Tabard, S., Anderson, R.A. and Millar, R.A. (2013) Kisspeptin Restores Pulsatile LH Secretion in Patients with NKB Signaling Deficiencies. Neuroendocrinology, 97, 193-202. http://dx.doi.org/10.1159/000336376

[134] Pingault, V., Bodereau, V., Baral, V., Marcos, S., Watanabe, Y., Chaout, A., Fouveaut, C., Leroy, C., Vener-Mine, O., Francannet, C., Dupin-Deguine, D., Hardelin, J.P., Dode, C. and Bondurand, N. (2013) Loss of Function Mutations in SOX10 Cause Kallmann Syndrome with Deafness. American Journal of Human Genetics, 92, 707-724. http://dx.doi.org/10.1016/j.ajhg.2013.03.024

[135] Jones, J. and Kemmann, E. (1976) Olfactory-Genital Dysplasia in the Female. Obstetrics \& Gynecology Annual, 5, 443-446.

[136] Casoni, F., Hutchins, I.B., Donohue, D., Fornaro, M., Condie, B.G. and Wray, S. (2012) 
SDF and GABA Interact to Regulate Aophilic Migration of GnRH Neurons. Journal of Cell Science, 125, 5015-5025. http://dx.doi.org/10.1242/jcs.101675

[137] Memi, F., Abe, P., Cariboni, A., Mackay, F., Parnavelas, J.G. and Stumin, R. (2013) CXC Chemokine Receptor 7 (CXCR7) Affects the Migration of GnRH Neurons by Regulating CXCL12 Availability. The Journal of Neuroscience, 33, 17527-17537. http://dx.doi.org/10.1523/JNEUROSCI.0857-13.2013

[138] Cariboni, A., Andrews, D.W., Memi, A.F., Ypsilanti, A.R., Zelina, P., Chedotal, A. and Parnavelas, J.G. (2012) Slit2 and Robo3 Modulate the Migration of GnRH Secreting Neurons. Development, 139, 3326-3327. http://dx.doi.org/10.1242/dev.079418

[139] Wray, S. (2010) From Nose to Brain, Development of Gonadotropin-Releasing Hormone-1 Neurons. Journal of Neuroendocrinology, 22, 743-753. http://dx.doi.org/10.1111/j.1365-2826.2010.02034.x

Submit or recommend next manuscript to SCIRP and we will provide best service for you:

Accepting pre-submission inquiries through Email, Facebook, LinkedIn, Twitter, etc. A wide selection of journals (inclusive of 9 subjects, more than 200 journals)

Providing 24-hour high-quality service

User-friendly online submission system

Fair and swift peer-review system

Efficient typesetting and proofreading procedure

Display of the result of downloads and visits, as well as the number of cited articles Maximum dissemination of your research work

Submit your manuscript at: http://papersubmission.scirp.org/ 